OFFSHORING AND VOLATILITY: MORE EVIDENCE FROM MEXICO'S MAQUILADORA INDUSTRY

\author{
Roberto A. CORONADO \\ RESEARCH DEPARTMENT \\ WORKING PAPER 1106
}




\title{
Offshoring and Volatility: More Evidence from Mexico's Maquiladora Industry
}

\author{
Roberto A. Coronado* \\ El Paso Branch \\ Federal Reserve Bank of Dallas \\ 301 East Main Street \\ El Paso, TX 79901-1326 \\ roberto.coronado@dal.frb.org
}

Tel. 915/521-5235

Draft Version: May 17, 2011

\begin{abstract}
In recent papers, Bergin, Feenstra, and Hanson (2007 \& 2009, hereafter BFH) analyze the impact that offshoring has in employment and output volatility, particularly on the Mexican maquiladora industry. Their empirical results indicate that employment and output in the offshoring manufacturing plants in Mexico are more volatile than their counterparts in the U.S. Such empirical results suggest that the maquiladora industry (offshoring) can help the U.S. industrial sector to better absorb shocks. In this paper, I expand BFH's empirical analysis in different directions. The empirical results I provide here suggest that the volatility in employment and output in Mexico's maquiladoras is greater than the one estimated by BFH. Therefore, offshoring via the maquiladora industry in Mexico can act as a greater cushion for business cycle fluctuations in the U.S.
\end{abstract}

Keywords: Business Cycles; Offshoring; Maquiladoras; Volatility.

JEL Classification Numbers: E32, F15.

\footnotetext{
" I am grateful to Chris Murray for his guidance and support. I would also like to thank David Papell, Dietrich Vollrath, Mark Wynne, Steven Craig and Bent Sorensen for helpful comments and suggestions. I also thank participants at the 2011 Association for Borderlands Studies Annual Meetings for comments and suggestions. All remaining errors are my sole responsibility. The views expressed here are those of the author and do not necessarily reflect those of the Federal Reserve Bank of Dallas or the Federal Reserve System.
} 


\section{Introduction}

The maquiladora industry serves as an ideal example to study offshoring and volatility given that American firms offshore a portion of their production processes to manufacturing plants in Mexico. Mexico is the third most important trading partner for the U.S., after Canada and China. In 2008, almost $\$ 367$ billion dollars were exchanged in goods and services between the two nations. This figure was roughly $\$ 27$ billion in 1980, representing a 13-fold increase over the past three decades. Offshoring has been the main channel for such dramatic boom in trade between the U.S. and Mexico. In particular, the maquiladora industry has been the major vehicle behind such vigorous growth in trade. In 2006, the trade related to the maquiladora industry comprised about half of the trade between the U.S. and Mexico. Today, maquiladoras employ 1.2 million people in Mexico, its production accounts for about 4\% of the country's gross domestic product, and are the second source of foreign exchange for the Mexican economy, behind oil.

There is a relatively abundant literature on offshoring, especially on how offshoring affects the volume of trade; however, the literature is scarce on how offshoring affects the variability of economic activity between trading partners. Bergin, Feenstra, and Hanson (2007 \& 2009) (BFH) provide seminal work analyzing the volatility that exists in different offshoring sectors in both the U.S. and Mexico. Their analysis considers the impacts of offshoring on the overall transmission of business cycle shocks.

Figures (1) - (6) show that volatility in output, total and production workers employment is higher in Mexico than in the U.S. The higher volatility in Mexico's maquiladora industries suggests that the U.S. is exporting volatility into Mexico. This in turn means that whenever the U.S. manufacturing sector receives a negative shock (recession) both output and employment are contracted far more in the offshoring plants in Mexico than in their U.S. counterparts. As a result, manufacturing output and workers in the U.S. are more insulated to business cycles because the maquiladora industry in Mexico absorbs the bulk of the shocks.

This paper expands the analysis of BFH in different directions with the main goal of shedding more light on the empirical results obtained by BFH. First, their data is from 1996 to 2005 and I expand the dataset to include data from 1990 to 2006 . This will prove valuable not only because of a larger time span but also to include more business cycle fluctuations (Mexican recession of 1994; U.S. recession of 1990-91). Secondly, I include data for other sectors not 
considered in the BFH analysis. Together these sectors comprise a significant portion of the offshoring in Mexico not considered by BFH. Thirdly, BFH use only two measures of industrial volatility: wage-bill and employment. I propose to expand their analysis by using U.S. industrial production indices for the different offshoring sectors. Industrial production indices are a comprehensive measure of industrial output and provide a better measure for overall volatility in the different manufacturing sectors. For employment, I use total and production workers employment for each sector. Fourth, BFH briefly analyze volatility at the state level, namely California and Texas. I depart from this by expanding the analysis to another border state, Arizona, and also by using the states in the Great Lakes Region. ${ }^{1}$ A natural venue is to analyze the volatility of Texas' and California's manufacturing sectors vis-à-vis Mexico's overall maquiladora activity given their strong economic ties to Mexico. Ruffin (1999) showed that the first trading partner for Texas is Mexico and that the bulk of the trade between Texas and Mexico is production sharing via the maquiladora industry. However, Arizona also shares a border with Mexico and the states in the Great Lakes area are considered the traditional manufacturing base in the U.S. and thus including them into the analysis will shed more light on how the maquiladora industry acts as a cushion for the overall U.S. industrial offshoring sectors.

The empirical results presented here can be summarized as follows. First, I document that employment volatility in Mexico is higher than in the U.S., contrary to conventional wisdom. Second, output fluctuations in Mexico are larger than previously documented by BFH. I show that output is close to 5 times more volatile in Mexico's maquiladora offshoring industries, controlling for aggregate volatility in both countries, while BFH documented output to be only 1.3 times more volatile in Mexico. Third, I obtain negative correlation coefficients for employment between offshoring industries in Mexico and the U.S. as well as between overall manufacturing. On the other hand, output between the two countries correlates on a positive fashion both at the offshoring sector and aggregate manufacturing sector.

Fourth, regression analysis indicates that employment (both total and production workers) and output in Mexico's maquiladora offshoring industries observe higher volatility than their counterparts in the U.S. even after controlling for bi-national differences and aggregate volatility. This result is robust to different regions in the U.S. such as Texas, California, Arizona and the Great Lakes region. Therefore, once I control for size, that is to match Mexico to an economy

\footnotetext{
${ }^{1}$ As defined by the U.S. Bureau of Economic Analysis
} 
similar in size, the same result emerges in the data. Employment and output regression results indicate that most of the offshoring industries observe higher volatility than aggregate manufacturing.

Fifth, the empirical results for the extensive and intensive margins indicate that in response to an increase in the share of aggregate employment in a maquiladora sector (holding aggregate employment constant); roughly 54 percent of the adjustment in the sector employment occurs at the extensive margin. In addition, the results presented here suggest that in response to an increase in aggregate employment (holding the share of industry employment constant) roughly one-third of the adjustment in sector employment occur at the extensive margin.

This paper is structured as follows. Section 2 briefly discusses the origins and evolution of the maquiladora industry in Mexico, as well as the business cycle ties to the U.S. economy. Previous studies on offshoring and volatility are summarized in Section 3. Section 4 describes the different datasets I employ in this paper. I take a look at the volatility and correlation of employment and output by analyzing standard deviations, relative standard deviations, and correlation coefficients for the offshoring sectors in the U.S. and Mexico in section 5. The econometric methods employed here are summarized in section 6 while the empirical results are described in section 7. Concluding remarks and ideas for future research are provided in section 8.

\section{Background on the maquiladora industry}

Mexico has evolved from practically a closed economy to an open economy over the past three decades. Today, Mexico has more free trade agreements with other countries (more than 50) than any other country in the world. During the 1930's and 1940's, Mexico closed its economy to the outside world by adopting a strategy based on import substitution industrialization. In the mid-1960's the U.S. ended the Bracero program, which main objective was to bring in Mexican workers to fulfill labor demand in the agricultural sector. With the end of the Bracero program, many Mexicans returned home and settled in northern Mexico. This in turn resulted in higher unemployment rates and growing poverty along Mexico's northern border region.

Contrary to the import substitution industrialization regime set in place, in 1965 Mexico launched the Border Industrialization Program, giving birth to the maquiladora industry. The maquiladora program was aimed at subsidizing foreign manufacturers that set up plants on the 
Mexican side of the border, creating jobs for Mexican nationals. Furthermore, the maquiladora program allowed plants to temporarily import supplies, parts, machinery, and equipment necessary to produce goods in Mexico duty-free as long as the output was exported back to the U.S. The U.S., in turn, taxed only the value-added portion of the manufactured product. ${ }^{2}$ In general, manufacturing companies carry out activities in the U.S. such as research and development, marketing and sales, and customer service; their headquarters are also in the U.S. The maquiladora plants in Mexico engage in the actual assembly and manufacturing of the products. About two-thirds of the maquiladora inputs come from U.S., while the rest comes from Asia. Virtually, all maquiladora production is exported to the U.S. ${ }^{3}$

The maquiladora industry experienced slow but steady growth during the early years. American manufacturing firms took advantage of the cheap labor force, particularly in the electronics, apparel and automotive sectors. Today, the maquiladora industry accounts for almost half of Mexico's exports and employs 1.2 million people, which represent roughly 10 percent of total formal employment in that country. Furthermore, the maquiladora industry is the second most important source of foreign exchange for the Mexican economy, after oil. About 80 percent of the maquiladoras in Mexico are of U.S. origin. Some of the American companies that currently have maquiladora plants in Mexico include Delphi Corp., Mattel, Sony Electronics, Ford Motor Co., and ITT Industries, just to name a few. At the same time, there are some maquiladora plants that assemble and manufacture products for different American companies. For instance, a single maquiladora can be the supplier of auto-harnesses to big car corporations like General Motors, Ford, Chrysler, Nisan, Toyota and Honda.

Since its inception, the maquiladora industry has experienced its ups and downs. This was exemplified by the first maquiladora downturn which took place in the mid-1970's. Employment declined by more than 11 percent as a result of a U.S. recession. Similar episodes occurred in 1982, in the early 1990s, and more recently, in the period of 2001-2003. All of these downturns coincide with U.S. recessions, particularly with contractions in the industrial sector. The opposite of this situation also holds true. The 1990's, especially the second half of the decade, marked an unprecedented record growth for the maquiladora industry, coinciding again with the boom in the U.S. business cycle.

\footnotetext{
${ }^{2}$ For a more detailed discussion on the origins and evolution of the maquiladora industry in Mexico, see Cañas and Coronado (2002).

${ }^{3}$ For more details regarding the origins of maquiladora inputs, see Cañas et al (2005).
} 
The maquiladora industry is well anchored to the U.S. business cycle. More importantly, the maquiladora industry typically responds on a greater proportion to the U.S. business cycle. That is, when the U.S. experiences a contraction, the maquiladora industry tends to contract even more. Similarly when the U.S. experiences a boom, the maquiladora industry responds with even more vigorous growth. In spite of the fact that the maquiladora industry is a key element in the economic relationship between Mexico and the U.S., little research has been conducted on how the maquiladora industry acts as a potential cushion and buffer to U.S. business cycles.

\section{Literature review}

The synchronization of business cycles among countries has received considerable attention in international macroeconomics literature over recent decades. Furthermore, recent empirical studies provide evidence that there exists a positive link between business cycle synchronization and bilateral trade (Frankel and Kose, 1998; Clark and van Wincoop, 2001; and Baxter and Kouparitsas, 2005). Many different theoretical mechanisms have been considered when studying such relationships between trade and the propagation of business cycles. In a recent paper, Burstein et al (2008) examine an alternative mechanism: production sharing. They argue that pairs of countries that are more engaged in production sharing also exhibit higher synchronization of business cycles. They develop a model of international business cycles to quantify the role of vertically integrated production sharing links in the transmission of a business cycle. Their results indicate that there is higher co-movement between productionsharing trade flows and output in the source country relative to non-production-sharing trade flows. Furthermore, their model indicates that there exists a positive link between the share of production sharing in total trade and output correlations in manufacturing. Given the strong presence of production-sharing in the bilateral trade between the U.S. and Mexico, Burstein et al (2008) paper provides a good perspective on the synchronization of business cycles between the two countries due to production sharing.

Lopez (2007) employs a simple two-sector small open economy model of real business cycles to analyze production sharing in Mexico's maquiladora industry. Lopez introduces the transmission channel of business cycles via demand shocks to the traded sector in the U.S. manufacturing sector. Such an RBC model is able to successfully mimic some of the business cycle characteristics of the Mexican economy; in particular the volatility of output and 
employment in the maquiladora industry, which are within 10 percent range of their data equivalents.

Using industry-level panel data, di Giovanni and Levchenko (2009) study how output volatility is related to trade openness. Their empirical results indicate that higher trade in a sector is associated with higher volatility in that same sector; while more trade also implies that the sector is less correlated to the rest of the local economy. They also find that higher overall trade openness comes with increased specialization in the economy. Furthermore, di Giovanni and Levchenko argue that the channels that link trade and volatility have become stronger over time. Among their findings, an interesting observation is that developing countries experience higher aggregate volatility when compared to developed economies. This last finding is of particular interest for the analysis presented in this paper.

In a recent paper, Zlate (2008) examines the effect of offshoring on the international transmission of business cycles by developing an international real business cycle model. Zlate's dynamic-stochastic-general-equilibrium (DSGE) model distinguishes between fluctuations in the number of offshoring firms (the extensive margin) and the value added per offshoring firm (the intensive margin) as separate transmission mechanisms. Furthermore, in Zlate's DSGE model firms are heterogeneous in labor productivity; they face a sunk entry cost in the domestic market and an additional fixed cost to produce offshore. Zlate provides four main empirical results. First, the model replicates the pro-cyclical pattern of offshoring that is consistent with the data from Mexico's maquiladora industry. More specifically, following an expansion in the parent country, there is an immediate spike in the intensive margin. On the other hand, the extensive margin responds in a more gradual fashion after an expansion in the parent country. Secondly, offshoring enhances the co-movement of output between the countries involved. Thirdly, offshoring reduces the price dispersion across countries. Lastly, offshoring enhances the procyclicality of investment and firm entry in the parent country, as the lower-cost alternative of offshoring increases the profitability of domestic firms.

As stated before, the analysis provided in this paper is based on the work by BFH. Therefore, it is important to summarize their research and empirical results. BFH's analysis concentrates in four maquiladora sub-sectors: (1) apparel manufacturing; (2) computer and electronic product manufacturing; (3) electrical equipment, appliance, and component manufacturing; and, (4) transportation equipment manufacturing (together these four represent 
three quarters of Mexico's offshoring production). BFH document that in all four maquiladora industries the volatility of economic activity in Mexico is significantly higher than in the U.S. In particular, they find that volatility in Mexico is twice as high as in the U.S. Thus, their results can be interpreted as Mexican maquiladoras acting as a cushion for the American industrial sector to better absorb shocks. ${ }^{4}$

Furthermore, BFH argue that one might suspect that this finding simply is the result of a more volatile Mexican economy. They offer three explanations why this is not the case. First, they document that overall manufacturing employment volatility is lower in Mexico than in the U.S. Secondly, even after controlling for size in Mexico's offshoring industries by comparing to state economies in the U.S., their results are robust. This indicates that Mexico's maquiladora sector is more volatile than its counterpart in the American border states in the U.S. Thirdly, one could argue that perhaps it is easier to hire and fire employees in Mexico; therefore, we should observe higher volatility in Mexico. However, Botero et al (2004) document that Mexico ties for the most regulated labor market among a sample of 85 countries whereas the labor market in the U.S. ranks as the fifth least regulated. Hence, in spite of tighter labor market regulations, maquiladoras' payrolls are more volatile than their counterparts in the U.S.

In addition, BFH investigate how volatility in maquiladora employment is allocated between extensive and intensive margins to verify the robustness of their empirical results. Their arguments for this is that higher volatility in offshoring industries in Mexico could be due to changes in scale in existing plants or to plants entering and exiting production. Their results indicate that volatility is present in both the intensive and extensive margins. In fact, they find that adjustments in the extensive margin account for one-third to one-half of the employment volatility in Mexico's maquiladora industry.

In summary, BFH document, via different techniques, that the maquiladora industry in Mexico is far more volatile than its counterpart in the U.S. Therefore, understanding the dynamics behind this volatility is of crucial importance. The purpose of this paper is to shed more light into this by expanding the BFH analysis into many directions.

\section{Data}

\section{Mexico's Data}

\footnotetext{
${ }^{4}$ Using a difference-in-difference regression, adapted for second moments, BFH find that in all four offshoring industries the volatility of economic activity in Mexico is significantly higher than in the U.S. Under this methodology they find similar results in a previous working paper. For more detail see Bergin et al (2007).
} 
The data used in this paper for the Mexican maquiladora industry come from the maquiladora monthly survey (Estadística de la Industria Maquiladora de Exportación, EIME) carried out by the Instituto Nacional de Estadística Geografía e Informática (INEGI). Under this dataset, INEGI reports data at the national, sector, state, and city level on employment, wages, number of plants, and value-added or output. I use both total employment and production workers employment, number of operating plants and output series at the national and sector level. INEGI publishes data for ten sectors: apparel, chemicals, electronics, food, furniture, leather, machinery, toys, transportation and services. The maquiladora sectors are matched with U.S. counterparts, dropping two sectors (toys and services) due to a lack of exact counterparts in the U.S. data. These eight sectors account for 85 percent of total maquiladora output and for 83 percent of total maquiladora employment.

Table 1 shows how the Mexican offshoring maquiladora sectors are matched with their counterparts in the U.S. For Mexico's overall manufacturing employment and output, I use data from the monthly manufacturing survey (Encuesta Industrial Mensual) carried out by INEGI as well. $^{5}$ The data sample is from January 1990 to December 2006. Output is deflated using Mexico's national consumer price index (CPI). The monthly maquiladora employment and output data are also used to construct quarterly and annual series. ${ }^{6}$ I then use monthly, quarterly, and annual series in the econometric analysis described below. ${ }^{7}$ I use different data frequencies to check the robustness of the empirical results presented in this paper.

Table 2 provides summary statistics for total employment data while Table 3 reports similar statistics for production workers employment data. Table 4 summarizes the output or valueadded data. Over the 1990-2006 period, the maquiladora sector employed, on average, almost 900,000 people with employment concentrated in electronics $(296,000$ jobs), transportation

5 As pointed out by BFH, the methodology of the Mexico's monthly manufacturing survey changed in 1994. Prior to 1994 , only 129 manufacturing sectors were monitored. In 1994, the survey coverage increased to 205 manufacturing sectors. In order to include time series for both employment and output for the sample period in my analysis, I had to create synthetic time series. Fortunately, the survey reports data under both methodologies during a 2 year overlapping period, 1994-1995. The way I build the synthetic time series is as follows:

$$
X_{t}^{N E W}=X_{t} * \frac{X_{\frac{N E W}{1994-95}}}{X_{\frac{O L D}{1994-95}}}
$$

${ }^{6}$ For the employment series, I take the average for the months corresponding to the quarter and take the average over the entire year to construct quarterly and annual employment series, respectively. With respect to output, I add output for the months corresponding to the quarter and add over the entire year to construct quarterly and annual output series, respectively.

${ }^{7}$ For the monthly and quarterly series, I use both raw data with monthly and quarterly dummies as well as seasonally adjusted data. I provide more details on the empirical results under both scenarios in Section 6 . 
$(188,000$ jobs $)$ and apparel (159,000 jobs) sectors. Overall manufacturing employment in Mexico, over the same time period, was close to 2.3 million jobs. Therefore, maquiladora employment in the eight sectors analyzed in this paper was roughly one-third of total manufacturing jobs in Mexico. Table 3 shows that there were roughly 1.7 million production workers, on average, nationwide in Mexico, and again one-third in the eight offshoring maquiladora sectors. Table 4 shows that the electronics, transportation and apparel sectors have the highest levels of production among the offshoring sectors analyzed here. The eight offshoring sectors account for only 7 percent of overall manufacturing output in Mexico over the 1990-2006 period.

\section{U.S. National Data}

For the U.S., I use monthly employment data from the Bureau of Labor Statistics and monthly industrial production indices from the Federal Reserve Board as a proxy for output. As mentioned before, BFH (2007) use the wage bill as a proxy for output in each of the four offshoring industries they analyze. However, I propose to use industrial production indices in this paper because they are the broadest monthly measure on real output we have available at the industry level, that is at the 3 -digit NAICS. ${ }^{8}$

The sample includes data from January 1990 to December 2006 for employment (total and production workers) and industrial production indices. Together these eight offshoring sectors account for 46 percent of total manufacturing employment (same figure is true for total employment and production workers employment) in the U.S. and account for almost 38 percent of total manufacturing output in the U.S. during the period of study for this project. Similar to the maquiladora data, I construct quarterly and annual series for employment and industrial production indices. ${ }^{9}$ I then use monthly, quarterly, and annual series in the econometric analysis described below. ${ }^{10}$ Again, the use of different data frequencies is to verify the robustness of the econometric results.

Table 2 reports summary statistics for the total employment data while Table 3 shows summary statistics for the production workers employment. The summary statistic for industrial production indices are provided in Table 4. Over the 1990-2006 period, the manufacturing

\footnotetext{
${ }^{8}$ Industrial Production and Capacity Utilization: Industrial Production Explanatory Notes, Federal Reserve Board.

${ }^{9}$ For both series, I take the average for the months corresponding to the quarter and take the average over the entire year to construct quarterly and annual series, respectively.

${ }^{10}$ For the monthly and quarterly series, I use both raw data with monthly and quarterly dummies as well as seasonally adjusted data. I provide more details on the empirical results under both scenarios in Section 6 .
} 
sector in the U.S. employed, on average, more than 16-million people with employment concentrated in transportation (1.944 million jobs), food (1.529 million jobs), machinery (1.346 million jobs) and chemicals (.968 million jobs). Production workers accounted for 11.7 million jobs over the same time span. Once more, transportation, food, machinery, and chemicals were the sectors that concentrated the most production employment.

\section{U.S. Regional Data}

In an attempt to expand and enrich the analysis presented here, I study fluctuations in total manufacturing employment and output volatility for some American border states like Texas and California. Both of these border states have a significant manufacturing presence and also have a strong trading relationship with Mexico, via the maquiladora industry. ${ }^{11}$ Furthermore, for completeness, I include Arizona into the analysis given that it also shares the border with Mexico. I excluded New Mexico because of the insignificant amount of trade it carries with Mexico, in spite of being along the border region. ${ }^{12}$

I expand BFH analysis by including interior states as well. Historically states in the Midwest are home to a significant portion of the manufacturing carried out in the U.S. I added the Great Lakes Region which comprises of the following states: Illinois, Indiana, Michigan, Ohio, and Wisconsin. I use both employment and output (gross state product) by sector as I do for Texas, California and Arizona.

For employment, I use total employment data from the U.S. Bureau of Economic Analysis Regional Economic Information System that is published on an annual frequency. More specifically, I use annual total employment data from 1990 through 2006 at the 3-digit NACIS. ${ }^{13}$ At the bottom of Table 2, I report summary statistics for the total employment data at the state level. Over the 1990-2006 period, the Great Lakes Region has by far the largest amount of manufacturing jobs, roughly 3.9 million jobs followed by California with 1.8 million jobs, Texas with 1 million jobs, and Arizona with close to 200,000 jobs. Unfortunately for both Arizona and the Great Lakes Region, transportation employment data are not available for the entire sample period, thus this important sector is dropped from the analysis for both areas.

\footnotetext{
${ }^{11} \mathrm{BFH}$ propose to match Mexico's maquiladora industry and states in an attempt to control for size differences. One of the arguments why Mexico's offshoring industries might be more volatile is that Mexico's economy is by far smaller than the U.S. Thus, by matching Mexico to specific states in the U.S., BFH show that their empirical results hold as well.

${ }^{12}$ New Mexico's top trading partners are China and Malaysia while Mexico comes in third place.

${ }^{13}$ Unfortunately, data for production workers are not available. Thus, I just use total employment.
} 
Similar to employment, the only fine-detail data available (that is, at the 3-digit NAICS level) on output at the state level is gross state product. Such output data are only available with an annual frequency resulting in a significant loss of observations. ${ }^{14}$ Furthermore, the data has a break in 1997 when the methodology changed from the Standard Industrial Classification (SIC) system to the North American Industrial Classification System (NAICS). To overcome this break in the data, I build a synthetic time series for each of the eight offshoring sectors for the different states by utilizing data from 1990 through 1997 under the SIC methodology and data from 1997 to 2006 under NACICS methodology. ${ }^{15}$

At the bottom of Table 4, I report summary statistics for the output data at the state level. Over the 1990-2006 period, the Great Lakes Region has by far the largest manufacturing output at $\$ 180$ billion dollars followed by California with $\$ 83$ billion, Texas with $\$ 54$ billion, and Arizona with $\$ 11$ billion. Unfortunately for the regional level, output data for the leather sector were not available, thus this sector is dropped from the regional analysis.

\section{A first look at volatility and correlation analysis}

Before engaging in the econometric analysis, I calculate simple standard deviations for employment and output series for the different offshoring sectors at the national level using monthly data and for the different offshoring sectors at the state or regional level using annual data. I report these second moment statistics in Tables 5 through 9. ${ }^{16}$ Each of these tables reports the standard deviation for both total and production workers employment for each of the eight offshoring sectors in the U.S. $\left(\sigma_{\mathrm{i}}^{\mathrm{US}}\right)$ and in Mexico's maquiladora $\left(\sigma_{\mathrm{i}}^{\mathrm{MX}}\right)$; as well as for the overall U.S.' manufacturing sector $\left(\sigma^{\mathrm{US}}\right)$ and for overall Mexico's manufacturing sector $\left(\sigma^{\mathrm{MX}}\right){ }^{17}$ To account for potential differences in volatility due to different sizes in offshoring industries in both countries, I also report a ratio that accounts for volatility in overall manufacturing sector in both the U.S. and Mexico. Similar statistics are reported for output at the bottom of each table.

\footnotetext{
${ }^{14}$ Specifically, I only have 64 observations for each equation I am interested in estimating.

15 The way I build the synthetic time series is as follows:$$
X_{t}^{N E W}=X_{t} * \frac{X_{1997}^{N E W}}{X_{1997}^{O L D}}
$$

${ }^{16}$ At the national level, I also computed similar tables with quarterly and annual data. I obtained very similar results as shown in the monthly tables. For brevity, I do not report quarterly nor annual volatility results but are available upon request.

${ }^{17}$ Mexico's overall manufacturing sector is composed of domestic manufacturing and maquiladoras. For more detail, see Encuesta Industrial Mensual, Instituto Nacional de Estadística y Geografía (2009).
} 
Table 5 shows that with the exception of the leather and allied product sector both employment and output volatility are higher in Mexico than in the U.S. On average for the eight offshoring sectors, total employment in Mexico is 2.2 times more volatile, production workers in Mexico is 1.9 times more volatile, and output is almost 3 times more volatile. Looking at specific sectors, the chemicals sector in Mexico is the most volatile sector with respect to its counterpart in the U.S. As pointed out by BFH, Mexican offshoring industries may be more volatile than their U.S. counterparts simply because at the aggregate level the Mexican economy is more volatile than the American economy. ${ }^{18}$ To control for such potential difference in aggregate volatility, I also report relative standard deviations. Once adjusted for overall manufacturing volatility in the U.S. and Mexico, total and production workers employment continue to be more volatile; 1.65 times and 1.5 times, respectively. Both volatility measures declined once I account for overall variation. On the other hand, output volatility increased significantly, once I controlled for overall variation, to close to 5 times more volatile. This is due to the fact that overall output volatility in Mexico is lower than in the U.S. while for both employment measures this is not the case.

Contrary to conventional wisdom, I show in Table 5 that volatility in Mexico's offshoring and overall manufacturing employment is higher than in their U.S. counterpart. It has been well documented that Mexico's labor laws are very rigid and it can be very expensive for firms to hire and fire people. ${ }^{19}$ The results I report here vary significantly from those found by BFH. I find that employment volatility in Mexico is higher both in offshoring industries and in total manufacturing with respect to the U.S. BFH find that volatility in offshoring industries is higher in Mexico but that is not the case for aggregate manufacturing. ${ }^{20}$ With respect to output, I find that, once I adjust for aggregate volatility, Mexico's offshoring industries are by far more volatile (4.82 times more volatile) while BHF find volatility to be much smaller (1.33 times more volatile). Given that the results presented here vary widely from those previously documented

\footnotetext{
${ }^{18}$ The argument is centered in the idea that since Mexico's economy is smaller than the U.S. then you would expect more volatility in economic activity in Mexico when compared to the U.S.

${ }^{19}$ Botero et al (2004) ranks countries in terms of job security laws restricting the hiring and firing of workers, Mexico is ranked among the most regulated among 85 countries included in the study while the U.S. ranks as the fifth least regulated labor market.

${ }^{20}$ The reason why my results differ from those obtained by BFH is most likely due to the fact that they concentrate in a few offshoring sectors for a shorter time frame, but most importantly they filter the data using HP. Therefore, it is likely that most of the volatility in the data is removed by such filter.
} 
by $\mathrm{BFH}$, it is worthwhile to investigate the dynamics of offshoring industries in Mexico within the dataset proposed in this paper in the previous section. ${ }^{21}$

Again, one argument as to why the Mexican offshoring sectors might be more volatile is size discrepancies. One might argue that since the Mexican economy is smaller than the U.S. economy, then it is not surprising that Mexico's offshoring industries are more volatile than their counterparts in the U.S. In order to partially offset the size differences, BFH compare Mexico to state economies in the U.S. such as Texas and California. I further expand this into incorporating Arizona, another border state that has a significant manufacturing sector and trades heavily with Mexico and also the Great Lakes region, the traditional manufacturing belt in the U.S. Tables 2 through 4 show that these four regional economies in the U.S. are more comparable in size to Mexico.

Table 6 compares volatility in Texas and Mexico and shows that employment is 4.2 times more volatile in Mexico, while output is 2.7 times more volatile in Mexico. Once I account for volatility in the aggregate manufacturing, employment in Mexico's offshoring industries is still 2.3 times more volatile than in their Texas counterparts while output is 3.1 times more volatile. Table 7 reports similar results for California and Mexico and we observe that employment is only 3.8 times more volatile in Mexico than in California while output is close to 4 times more volatile in the maquiladora industry than in California's manufacturing sector. Again, once I account for volatility in the aggregate manufacturing, employment in Mexico's offshoring industries is still 2.8 times more volatile than in their California counterparts while output is 3.5 times more volatile.

Table 8 illustrates volatility in Arizona and Mexico's maquiladora industry with employment south of the border being 2.4 times more volatile while output 3.5 times more volatile. Accounting for volatility in the aggregate manufacturing, employment in Mexico's offshoring industries is still 1.7 times more volatile than in their Arizona counterparts while output is 5.2 times more volatile. Finally, Table 9 shows that employment is close to 5 times more volatile in Mexico than in the Great Lakes Region while output is 4.8 times more volatile in Mexico. Controlling for aggregate manufacturing volatility, employment in Mexico's offshoring industries is still 3.8 times more volatile than in their Great Lakes Region counterparts while

\footnotetext{
${ }^{21}$ My dataset differs from BFH in three main aspects: (1) sample span is larger (1990-2006 vs. 1996-2005), (2) I include more offshoring sectors, (3) more importantly I do not filter the data using HP filter.
} 
output is 2.5 times more volatile. In summary, we observe that volatility, both in employment and output, is more severe in Mexico's offshoring maquiladora industry than overall in the U.S. and at the state level as well, even after accounting for differences in aggregate manufacturing volatility in both sides of the border.

Tables 10 through 14 report correlation coefficients for offshoring industries between and within Mexico and the U.S. Of particular interest is the negative correlation coefficient that exists for total employment and production workers in overall manufacturing and across most offshoring industries between Mexico and the U.S. (see Table 10). On average such correlation coefficients range from -0.21 to -0.28 indicating that employment in both countries moves in the opposite direction. On the other hand, output correlation coefficients show a positive correlation. The correlation in output across offshoring industries averages 0.52 while it is 0.91 for overall manufacturing output. This suggests that manufacturing production clearly moves together in both the U.S. and Mexico in the aggregate and across offshoring industries.

Different patterns emerge in the regional correlation coefficients reported in Tables 11-14. For instance, positive correlation coefficients are present across most of the offshoring industries for both employment and output for Texas (Table 11) and for Arizona (Table 13). However, this is not the case for California (Table 12) and the Great Lakes area (Table 14). The employment correlations for these two regions are very much aligned with their national aggregate manufacturing employment; nonetheless, most of the correlation coefficients are negative between offshoring industries across the border. With respect to output, most of the correlations are positive for Texas, Arizona, and California, yet for the Great Lakes region this is not the case; most of the correlation coefficients are negative between output in Mexico's offshoring industries and the counterparts in the manufacturing belt in the Great Lakes area.

The results presented here, again, contrast those documented previously by BFH. BFH find positive correlation for both employment and wage bill across all offshoring industries they include in their study. BFH find similar results, positive correlation coefficients, for their state level (regional) analysis across industries. Thus, once I expand the sample-span, include more

offshoring sectors, and not filtering the data with the HP filter, I observe different dynamics in my dataset.

\section{Econometric analysis}

Measuring volatility in offshoring industries in Mexico 
The main purpose of this paper is to examine the volatility, both in employment and output, between the U.S. offshoring manufacturing sectors and the Mexican maquiladora sectors. Figures 1, 2 and 3 illustrate the volatility in output, total employment, and production workers employment, respectively, measured as the difference in logs, for both the U.S. and Mexican manufacturing sectors. Furthermore, Figures 4, 5 and 6 show the volatility in output, total employment, and production workers employment, respectively, for the eight different offshoring sectors studied in this paper. In all figures, we can easily observe that the maquiladora offshoring sectors are by far more volatile than their U.S. counterparts across the board.

Let $Y_{i c t}$ be the $\log$ employment or $\log$ output in industry or sector $i$, in country $c$ (either Mexico or the U.S.) at time $t$. I use the squared deviation from the mean, $\left(Y_{i c t}-\bar{Y}_{i c}\right)^{2}$, as a standard measure of volatility, where $\bar{Y}_{i c}$ is the mean value of either log employment or $\log$ output in industry $i$ and country $c$ over the sample period. Furthermore, I pool observations on $\left(Y_{i c t}-\bar{Y}_{i c}\right)^{2}$ for both countries across time and across offshoring sectors. Also, I include in the sample pooled observations on $\left(Y_{i c t}-\bar{Y}_{i c}\right)^{2}$ in aggregate manufacturing in the two countries, yielding a data set with $2 * 2 * T$ observations, where $T$ is either the number of months (204 months), the number of quarters (68 quarters), or the number of years (17 years) for each of the eight sectors I am interested in analyzing. Thus, I have either 816 observations for the monthly dataset, 272 observations for the quarterly dataset, or 68 for the yearly dataset for each equation I estimate. Another main difference between the analysis proposed here and the one carried out by BFH is that I do not filter the data; that is, BFH use the Hodrick-Prescott (1997) filter to "clean" the seasonally adjusted data. By doing this, it is likely that much of the data variability is either eliminated or altered and the actual dynamics that lie in the data are not captured in their analysis. $^{22}$ The data series used here, employment and output, exhibit an upward drift or trend which makes them nonstationary, and standard tests suggest they have a unit root. Cogley and Nason (1995) document that when applied to persistent time series, the HP filter can generate business cycles dynamics even if none are present in the original data. ${ }^{23}$ Similarly, Murray (2003) documents that the Baxter-King band-pass filter, and in general any band-pass filter, does

\footnotetext{
${ }^{22}$ I also estimate all regressions using raw data and include dummy variables to control for seasonal factors in the data. For brevity, I do not report such results but they are available upon request.

${ }^{23}$ Cogley and Nason (1995) document that the Hodrick-Prescott band-pass filter provides a spurious cyclical component for the U.S. gross domestic product.
} 
not isolate the cycle in an unobserved components model with a stochastic trend. Furthermore, it has been documented that filtered I(1) processes exhibit AR(2) cyclical dynamics and strong cross-correlations. To avoid this potential pitfall, I abstain from employing the HP filter.

Following the footsteps of BFH (2007), I formally examine the relative volatility of the U.S. offshoring industries and Mexican maquiladora sectors, controlling for aggregate differences in volatility, by estimating the following regression:

$$
\left(Y_{i c t}-\bar{Y}_{i c}\right)^{2}=\beta_{0}+\beta_{1} C D+\beta_{2} O D+\beta_{3}(C D * O D)+\varepsilon_{i c t}
$$

where $\mathrm{CD}$ is a country dummy that takes the value of one if country $c$ is Mexico and zero if country $c$ is the U.S.; OD is an offshoring dummy that takes the value of one if industry $i$ is an offshoring industry and zero if industry $i$ is the aggregate manufacturing sector; and $\varepsilon_{i c t}$ is a disturbance term. The main coefficient of interest is the interaction-term, $\beta_{3}$, which captures the difference in volatility in employment or output of offshoring industries in Mexican maquiladoras. Furthermore, the regression above controls for aggregate differences in variability between Mexico and the U.S. captured by $\beta_{1}$ (main effect on the Mexico dummy) and also controls for differences in variability between offshoring industry and aggregate manufacturing captured by $\beta_{2}$ (main effect on the offshoring industry dummy).

Since the above equation is estimated separately for each of the eight offshoring industries, I allow the sector-specific volatility to be incorporated into the econometric analysis. Furthermore, BFH argue that given that the regressand is the square of a variable, the error term is likely to have a non-spherical distribution; therefore, inference might not be straightforward. In order to overcome this potential econometric issue, I use bootstrap methods to obtain the standard errors for the different coefficient estimates. ${ }^{24}$

A nother look at volatility: the case of the intensive vs. extensive margins

In a more recent paper, BFH (2009) engage into a different econometric analysis from the one described above. Again, the main purpose is to study how volatility in Mexico's offshoring maquiladora sectors can act as shock absorber for U.S. manufacturing industries. In essence, they study how volatility in employment is allocated between the intensive and extensive margins. In particular, this type of econometric analysis provides evidence whether the volatility in the offshoring industries can be attributed to either changes in scale in existing plants

\footnotetext{
${ }^{24}$ I obtain the standard error of the coefficients by employing bootstrapping techniques, using 10,000 repetitions.
} 
(employment per operating plant) or to plants entering or exiting the production process (number of plants). ${ }^{25}$ Following their footsteps, I estimate the following regressions, using monthly data for the period 1990:01 through 2006:12 for the eight offshoring maquiladora sectors:

$$
\begin{aligned}
& \ln N_{i t}=\delta_{1}+\delta_{2} \ln \frac{E_{i t}}{E_{t}}+\delta_{3} \ln E_{t}+\varepsilon_{i t} \\
& \ln \frac{E_{i t}}{N_{i t}}=\alpha_{1}+\alpha_{2} \ln \frac{E_{i t}}{E_{t}}+\alpha_{3} \ln E_{t}-\varepsilon_{i t}
\end{aligned}
$$

where $N_{i t}$ is the number of plants in industry $i$ at time $t, E_{i t}$ is employment in industry $i$ at time $t$, $E_{t}$ is total maquiladora employment, $\frac{E_{i t}}{N_{i t}}$ is the number of employees per plant in industry $i$ at time $t, \frac{E_{i t}}{E_{t}}$ is the share of employment in industry $i$ at time $t$ with respect to total maquiladora employment, and $\varepsilon_{i t}$ are the idiosyncratic error terms. I conduct the econometric analysis for both total employment and production workers employment. By construction, $\delta_{1}+\alpha_{1}=0$, $\delta_{2}+\alpha_{2}=1$, and $\delta_{3}+\alpha_{3}=1$. The relative magnitude of the parameter estimates indicates how aggregate shocks affect the number of plants ( $N_{i t}$ or the extensive margin) and employment per plant $\left(\frac{E_{i t}}{N_{i t}}\right.$ or the intensive margin).

\section{Econometric results}

National monthly dataset

Table 15 reports the empirical results for total employment under the monthly dataset. ${ }^{26}$ The country dummy effect is positive but not statistically significant under all individual regressions (except for the Food sector), indicating that volatility in employment is somewhat higher in Mexico than in the U.S. For four offshoring sectors - electronics, apparel, leather and foodvolatility is higher than aggregate manufacturing as the positive and statistically significant offshoring dummy estimates indicate. More importantly the coefficient of interest, which is the interaction term, is highly significant and positive for all offshoring sectors except leather,

\footnotetext{
${ }^{25}$ The idea here is that firms compare the unit-labor costs across borders. BFH argue that wages tend to be procyclical so when the U.S. has a boom in demand (shock) this in turn affects the offshoring decision of some firms. Given the increase in home wages due to boom in demand, home workers become relative more expensive; therefore, firms that did not offshore before might now find it profitable. "This shift in the extensive margin acts as a powerful mechanism for the international transmission of shocks, whereby U.S. producers shift unusually high levels of production abroad during a domestic boom, and the reverse during a recession." (BFH 2009b, p. 3)

${ }^{26}$ The econometric results presented here for the national dataset correspond to monthly seasonally adjusted data. I alternatively estimated all regressions with raw monthly data and included seasonal dummies. The empirical results under both methodologies are very similar. For brevity reasons, I only report the monthly seasonally adjusted results, but the other empirical results are available upon request.
} 
suggesting that volatility in Mexico's offshoring industries is higher than the corresponding industries in the U.S.; even after controlling for the bi-national differences and variability for aggregate manufacturing. ${ }^{27}$

Table 16 reports empirical results for production workers. The positive and significant offshoring industry dummy regressor indicates that the electronics, apparel, and leather offshoring sectors observe higher variability than the aggregate manufacturing sector. For the food industry the opposite is true. Again, the Mexico dummy coefficient is positive across offshoring sectors but not statistically significant (except for the Food sector); suggesting that production workers employment volatility in Mexico is somewhat higher than in the U.S. Looking at the regressor of interest, the interaction term, all sectors exhibit a positive and significant interaction term, again with the exception of leather, indicating that even after controlling for country and aggregate volatility, production workers employment in the offshoring sectors in Mexico are more volatile than their U.S. counterparts. Therefore, in spite of tighter labor markets in Mexico, offshoring industries in Mexico observe a higher degree of volatility in their payrolls, both in total and production workers employment.

Table 17 reports regression results for output. Similar to the results presented before based on the standard deviation analysis, we observe that output volatility in Mexico is smaller across the offshoring sectors than in the U.S., as the country dummy regressors are negative and statistically significant for most of the sectors. Looking at the output variability for the offshoring industries versus the volatility in the aggregate manufacturing sector, I find mixed results. For three sectors - electronics, transportation, and food-I document that volatility in these offshoring sectors is lower than in the aggregate manufacturing sector; yet for other sectors, such as apparel and leather, volatility in these offshoring sectors is higher than in the overall manufacturing sector. Similar to the empirical results for employment, I find that output volatility is higher in Mexico's maquiladora industry across sectors, with the exception of leather, even after controlling for bi-national differences (country dummy) and for aggregate volatility (offshoring dummy).

The empirical results offered here indicate that the maquiladora industry is more volatile in terms of total employment, production workers employment, and output than its counterparts in

\footnotetext{
${ }^{27}$ When the opposite is true, such as in the case of the leather sector, the interaction coefficient is negative and significant, and it implies that variability in Mexico's offshoring industries is lower than in the corresponding American industries, even after controlling for variability in bi-national differences and aggregate manufacturing.
} 
the U.S. This empirical fact holds even after controlling for differences across countries and across aggregate manufacturing volatility. Furthermore, these results corroborate the idea that the maquiladora industry acts as a potential buffer for business cycle shocks experienced in the U.S. (see Zlate (2009) and BFH (2007, 2009)). This empirical finding has not been extensively documented in the economics literature; therefore, the purpose of this paper is to provide more evidence in favor of this empirical fact. It has been well documented that the maquiladora industry provides benefits to the U.S. manufacturing industry mostly via cheaper labor and proximity to final markets, namely consumers. The empirical results provided here exacerbate the benefits of the maquiladora industry to the U.S. manufacturing industry via a potential mechanism for shock absorption.

In addition to the monthly regression analysis presented above, I also engaged in regression analysis employing quarterly and annual data. ${ }^{28}$ For brevity purposes, I only report here the empirical results for the monthly dataset. However, I obtain the same empirical results under the other two frequency-datasets: quarterly and annual. Such empirical results are available upon request.

\section{U.S. regional empirical results:}

Tables 18 and 19 show the regression results for Texas employment and output, respectively. ${ }^{29}$ The offshoring regressor resulted positive and statistically significant for the employment regressions in two cases, apparel and leather, suggesting that employment in these two offshoring sectors is more volatile than aggregate manufacturing employment. The main regressor, the interaction term, resulted positive and significant in all regressions with the exception of employment in the apparel and leather sectors. This indicates that volatility in employment, in practically all Mexico's maquiladora industries, is statistically higher than in Texas. With respect to output, the only regressor that resulted statistically significant across all offshoring industries was the interaction term. This in turn suggests that output is more volatile in Mexico's offshoring industries than in their counterparts in Texas, even after controlling for differences in regions (country dummy) and overall manufacturing volatility (offshoring dummy).

\footnotetext{
${ }^{28}$ Similar to the monthly data, for the quarterly dataset I used seasonally adjusted data and raw quarterly data with quarterly seasonal dummies. I obtained the same empirical results under both regression specifications.

${ }^{29}$ Unfortunately, Texas output data for leather (NAICS 316) sector were not available.
} 
Tables 20 and 21 show the regression results for California employment and output, respectively. ${ }^{30}$ Overall the empirical results are quite similar to those for Texas. For employment, the offshoring regressor resulted positive and statistically significant in two cases, transportation and leather, suggesting that employment in these two offshoring sectors is more volatile than aggregate manufacturing employment. The main regressor, the interaction term, resulted positive and significant in all regressions with the exception of employment in the apparel and leather sectors. This indicates that volatility in employment, in practically all Mexico's maquiladora industries, is statistically higher than in California. For output, the interaction term resulted positive and statistically significant across the sectors, indicating that output in Mexico's maquiladora industry is higher than in California.

Tables 22 and 23 show the regression results for Arizona employment and output, respectively. ${ }^{31}$ Again, the empirical results for Arizona are quite similar to those obtained for Texas and California. The offshoring regressor resulted positive and statistically significant in two cases, apparel and leather, suggesting that employment volatility in these two offshoring sectors is higher than aggregate manufacturing employment. The main regressor, the interaction term, resulted positive and significant in all regressions with the exception of employment in the leather sector. This indicates that volatility in both employment and output, in practically all Mexico's maquiladora industries, is statistically higher than in Arizona.

Tables 24 and 25 show the regression results for the Great Lakes area employment and output, respectively. ${ }^{32}$ The empirical results for the Great Lakes region are quite similar to those obtained for the other states analyzed here: Texas, California and Arizona. The offshoring regressor resulted positive and statistically significant only for the leather sector suggesting that employment volatility in this offshoring industry is higher than aggregate manufacturing employment. The main regressor, the interaction term, resulted positive and significant in all regressions with the exception of employment in the leather sector. This indicates that volatility in both employment and output, in practically all Mexico's maquiladora industries, is statistically higher than in the Great Lakes area.

\footnotetext{
${ }^{30}$ Similar to Texas, output data for California for the leather (NAICS 316) sector were not available.

${ }^{31}$ Employment data for the transportation (NAICS 336) sector and output data for the leather (NAICS 316) sector were not available.

${ }^{32}$ Employment data for the transportation (NAICS 336) sector and output data for the leather (NAICS 316) sector were not available.
} 
After analyzing into detail the dynamics of volatility between Mexico's maquiladora offshoring industry and regional economies in the U.S., there are a few general characteristics that surface. First, the country dummy resulted positive but not significant in all employment regression cases indicating that employment is perhaps more volatile in Mexico's maquiladora industry. Again, these results were not significant, but weakly indicate that employment in Mexico is more volatile across offshoring industries than their counterparts in different regions in the U.S. Secondly, the country dummy for the output regressions indicated mixed results, albeit none of them resulted statistically significant. For Texas and Arizona, the country regressor resulted negative in almost all industries, while for California and the Great Lakes region the opposite is true. Thirdly, the offshoring dummy variable resulted positive in practically all regressions for both employment and output, but only significant in a few cases, indicating that overall offshoring industries observe higher volatility in employment and output than the aggregate manufacturing industry. Fourthly, and perhaps the most important regional result, the regressor of interest, the interaction term, resulted positive and statistically significant in the vast majority of regressions, suggesting that both employment and output in Mexico's maquiladora offshoring industries observe higher volatility than their counterparts in the different U.S. regions.

\section{Comparing empirical results to $\mathrm{BFH}$}

Even though my results are similar to the ones obtained by BFH, they are different in some aspects. First, under the national output dataset, BFH obtain all regressors positive and significant, specifically the country and offshoring dummies as well as the interaction term. Once BFH engage in the national employment regression analysis, they obtain a negative and significant coefficient for the country dummy, indicating that employment in Mexico is less volatile than in the U.S. However, the results presented here indicate that the country dummy is positive across most of the offshoring sectors and across all regions; however, they are not statistically significant. The reason behind such difference can be found by looking at the standard deviations. I show in Table 5 that the standard deviation in employment is higher in Mexico both at the aggregate manufacturing level as well as the offshoring sector level compared to the U.S. I show similar results for the regional analysis (see Tables 6-10). BFH, on the other hand, obtained a lower standard deviation for aggregate manufacturing employment (both at the national and regional level) in Mexico compared to the U.S. The difference is probably the 
result of a different time span in the analysis and also due to the different adjustments to the data as previously explained. Therefore, I show in my analysis, that in spite of existing research documenting that Mexico has tighter labor laws (making it difficult for business to adjust payrolls in response to business conditions), employment at the aggregate and at the offshoring sector level is more volatile than in the U.S.

Second, BFH find, for the most part, all three regressors to be statistically significant. On the other hand, the empirical results presented here indicate that the only regressor to be statistically significant across offshoring sectors and across regions is the interaction term, the regressor of interest. Therefore my results provide more succinct empirical evidence that offshoring under Mexico's maquiladora industry exhibit higher volatility in employment and output with respect to U.S. counterparts.

Extensive vs. intensive margin empirical results

Table 26 reports the regression results for the extensive and intensive margin analysis for both total employment and production workers employment. The data used for the regression are pooled across the eight offshoring maquiladora industries and is monthly from January 1990 through December 2006. Also, the data have been seasonally adjusted. Under total employment regression results, $\delta_{2}=0.54$ and $\delta_{3}=0.33$, only $\delta_{2}$ is statistically significant. These empirical results suggest that in response to an increase in the share of aggregate employment in a maquiladora sector (holding aggregate employment constant), roughly 54 percent of the adjustment in the sector employment occurs at the extensive margin. Furthermore, these empirical results also suggest that in response to an increase in aggregate employment (holding the share of industry employment constant), roughly one-third of the adjustment in sector employment occurs at the extensive margin.

The results for the production workers regressions analysis are similar. For instance, under production workers employment regression results, $\delta_{2}=0.55$ and $\delta_{3}=0.39$, only $\delta_{2}$ is statistically significant. Again, these empirical results suggest that in response to an increase in the share of aggregate production workers employment in a maquiladora sector (holding aggregate production workers employment constant), roughly 55 percent of the adjustment in the sector production workers employment occurs at the extensive margin. Also, these empirical results also suggest that in response to an increase in aggregate production worker employment (holding 
the share of industry production worker employment constant), roughly 40 percent of the adjustment in sector production workers employment occurs at the extensive margin.

The results presented here differ from those reported by BFH (2009). In a nutshell, the results reported by BFH are the opposite of the ones reported in this paper. That is, BFH report that over one-third of the adjustment in industry employment occurs at the extensive margin, given an increase in the share of aggregate employment in an offshoring industry (holding aggregate employment constant). Also, BFH document that nearly one-half of adjustment in industry employment takes place at the extensive margin in response to an increase in aggregate employment (holding the industry employment share constant). Therefore, once I expand the dataset into more offshoring sectors and greater sample span, and leave the data unfiltered, I obtain different empirical results. Thus, the empirical results are sensitive to both sample period and data adjustments. For comparison purposes, I limited my dataset to the four offshoring industries and to the exact sample span used by BFH; the results obtained are very similar to the ones reported here. Therefore, the main reason behind the difference between empirical results lies on filtering the data using HP. ${ }^{33}$

\section{Concluding remarks and future research}

In this paper, I expand the pioneering empirical research of BFH (2007 \& 2009) on how offshoring affects volatility. I use more extensive datasets than BFH such as a larger sample span as well as more offshoring sectors. I further match Mexico's maquiladora industry to other regions in the U.S. Most importantly, I refrain from filtering the data using the HP filter. My empirical results to some extent are similar to those previously obtained by BFH, but there are clearly differences.

The empirical results presented here can be summarized as follows. First, I document that employment volatility in Mexico is higher than in the U.S. (both at the aggregate and sector level), contrary to conventional wisdom. Second, output fluctuations in Mexico are larger than previously documented by BFH. I show that output is close to 5 times more volatile in Mexico's maquiladora offshoring industries, after controlling for aggregate volatility in both countries, while BFH documented output to be only 1.3 times more volatile in Mexico. Third, I obtain negative correlation coefficients for total employment and production workers employment

\footnotetext{
${ }^{33}$ As I show in the volatility and other regression results, my results are different from those obtained by BFH. Most likely the reason behind this is that they filter the data using HP filter, while I do not filter the data.
} 
between offshoring industries in Mexico and the U.S., as well as between overall manufacturing. On the other hand, output between the two countries correlates on a positive fashion both at the offshoring sector and aggregate manufacturing sector. Fourth, regression analysis indicates that employment (both total and production workers) and output in Mexico's maquiladora offshoring industries observe higher volatility than their counterparts in the U.S. This result is also robust to different regions in the U.S. such as Texas, California, Arizona and the Great Lakes region. Therefore, once I control for size (that is, match Mexico to an economy similar in size) the same result emerges in the data. Fifth, the empirical results for the extensive and intensive margin indicate that in response to an increase in the share of aggregate employment in a maquiladora sector (holding aggregate employment constant); roughly 54 percent of the adjustment in the sector employment occurs at the extensive margin. Finally, the results presented here suggest that in response to an increase in aggregate employment (holding the share of industry employment constant); roughly one-third of the adjustment in sector employment occurs at the extensive margin.

The empirical results offered here indicate that the maquiladora industry is more volatile in terms of total employment, production workers employment, and output than the counterpart in the U.S. This empirical fact holds even after controlling for differences across countries and across aggregate manufacturing volatility. Furthermore, these results corroborate the idea that the maquiladora industry acts as a potential buffer for business cycle shocks experienced in the U.S. (see Zlate (2009) and BFH (2007,2009)). This empirical finding has not been extensively documented in the literature and as a result the purpose of this paper is to fill this gap. It has been well documented that the maquiladora industry provides benefits to the U.S. manufacturing sector mostly via cheaper labor and proximity to the final market. Therefore, the empirical results provided here exacerbate the benefits of the maquiladora industry to the U.S. manufacturing industry via a potential mechanism for shock absorption.

Given that this research is relatively new, there are still many loose ends that need to be addressed in future research. First, a good idea would be to break the dataset in different time spans to test whether volatility has changed over the past two decades; for instance, (1) pre- and post-Mexico joining NAFTA and (2) pre- and post-2000, as other research suggests that the maquiladora industry changed significantly during 2000-2001 as a result of many factors: China's entrance to WTO, NAFTA rules change, U.S. recession (see Canas et al (2010)). 
Secondly, it will prove valuable to match U.S. border states to adjacent Mexican border states and not to the overall maquiladora activity as I just did in this paper. Maquiladora data is available at the state level for the eight offshoring sectors I analyze here; therefore, matching states along the U.S.-Mexico border region will perhaps be more suitable than the approach taken here. Thirdly, Canada is a crucial element in the transportation sector in North America. Thus, incorporating Canada (at least in the transportation sector) into the analysis will be a good idea. Obviously, some of these ideas are more ambitious than others, and some ideas are more feasible than others. 


\section{References}

Baxter, Marianne and Kouparitsas, Michael A. (2005), "Determinants of business cycle comovement: a robust analysis," Journal of Monetary Economics, 52(1), 113-158.

Bergin, Paul R., Feenstra, Robert C., and Hanson, Gordon H. (2007), "Offshoring and Volatility,” NBER Working Paper No. 13144.

Bergin, Paul R., Feenstra, Robert C., and Hanson, Gordon H. (2009), "Offshoring and Volatility," A merican Economic Review, 99(4), 1664-1671.

Bergin, Paul R., Feenstra, Robert C., and Hanson, Gordon H. (2009b), "Volatility Due to Offshoring: Theory and Evidence," Working Paper available at http://irps.ucsd.edu/assets/027/9475.pdf.

Burstein, Ariel, Kurz, Christopher, and Tesar, Linda (2008), "Trade, production sharing, and the international transmission of business cycles," Journal of Monetary Economics, 55(4), 775-795.

Botero, Juan C., Djankov Simeon, La Porta, Rafael, Lopez-de-Silanes, Florencio, and Shleifer, Andrei (2004), "The Regulation of Labor," Quarterly Journal of Economics, 119(4), 1339-1382

Cañas, Jesus and Coronado, Roberto (2002), "Maquiladora Industry: Past, Present and Future," Federal Reserve Bank of Dallas, El Paso Branch, Business Frontier, Issue 2.

Cañas, Jesus, Coronado, Roberto and Gilmer, Robert W. (2005), "Texas Border Employment and Maquiladora Growth," The Face of Texas: Jobs, People, Business, Change, Federal Reserve Bank of Dallas

Cañas, Jesus, Coronado, Roberto, Gilmer, Robert W., and Saucedo, Eduardo (2010), "The Impact of the Maquiladora Industry along the U.S.-Mexico Border" working paper, forthcoming, Federal Reserve Bank of Dallas.

Clark, Todd E., and van Wincoop, Eric (2001), "Borders and business cycles," Journal of International Economics, 55(1), 59-85.

Cogley, Timothy, and James N. Nason (1995), "Effects of Hodrick-Prescott filter on trend and difference stationary time series: Implications for business cycle research" Journal of Economic Dynamics and Control, Vol. 19, pp. 253-278.

di Giovanni, Julian, and Andrei A. Levchenko (2009), "Trade Openness and Volatility," The Review of Economic and Statistics, 91(3), pp. 558-585.

Frankel, Jeffrey A., and Kose, Andrew K. (1998), "The endogeneity of the optimum currency area criteria," Economic Journal, 108, 1009-1025.

Hodrick, Robert J., and Edward C. Prescott (1997), "Postwar U.S. Business Cycles: An Empirical Investigation" Journal of Money, Credit and Banking, Vol. 29, No. 1, pp. 1-16. 
Instituto Nacional de Estadística y Geografía (2009), "Encuesta Industrial Mensual: Ampliada," available at: www.inegi.org.mx, July 2009.

Lopez, Jose Joaquin (2007), "Production Sharing and Real Business Cycles in a Small Open Economy," Federal Reserve Bank of Dallas, Globalization and Monetary Policy Institute Working Paper No. 5.

Murray, Christian J. (2003), "Cyclical Properties of Baxter-King Filtered Time Series," The Review of Economics and Statistics 85: 472-476.

Ruffin, Roy J. (1999), “The Nature and Significance of Intra-Industry Trade," Economic and Financial Review, Federal Reserve Bank of Dallas

Zlate, Andrei (2008), "Offshore Production and Business Cycle Dynamics with Heterogeneous Firms," Federal Reserve Board Working Paper. 
Table 1. Maquiladora sector matching with U.S. industrial sectors Maquiladora Sector U.S. Industrial Sector

Apparel

Apparel (315)

Chemicals

Chemicals (325)

Electronics

Electrical equipment, appliance and components (335)

Food

Food (311)

Furniture

Furniture and related products (337)

Leather

Leather (316)

Machinery

Machinery (333)

Transportation

Transportation equipment (336)

Notes: NAICS codes in parentheses. Together these sectors comprise about 85 percent of total maquiladora output for the 1990-2006 period. 
Table 2. Total Employment Summary Statistics

\begin{tabular}{|c|c|c|c|c|c|c|c|c|c|}
\hline & $\begin{array}{l}\text { Total } \\
\text { Mfg. }\end{array}$ & $\begin{array}{c}\text { Apparel } \\
\text { (315) }\end{array}$ & $\begin{array}{c}\text { Chemicals } \\
\text { (325) }\end{array}$ & $\begin{array}{c}\text { Electrical } \\
\text { equipment, } \\
\text { appliance and } \\
\text { components }(335)\end{array}$ & $\begin{array}{l}\text { Food } \\
(311)\end{array}$ & $\begin{array}{l}\text { Furniture and } \\
\text { related products } \\
(337)\end{array}$ & $\begin{array}{c}\text { Leather } \\
\text { (316) }\end{array}$ & $\begin{array}{c}\text { Machinery } \\
\text { (333) }\end{array}$ & $\begin{array}{c}\text { Transportation } \\
\text { equipment } \\
(\mathbf{3 3 6 )}\end{array}$ \\
\hline \multicolumn{10}{|l|}{ Mexico } \\
\hline Mean & $2,293.3$ & 158.7 & 18.9 & 296.2 & 10.0 & 45.0 & 7.3 & 11.5 & 187.6 \\
\hline Std. Dev. & 247.8 & 79.6 & 8.2 & 88.8 & 1.5 & 12.2 & 1.3 & 5.6 & 55.6 \\
\hline Obs. & 204 & 204 & 204 & 204 & 204 & 204 & 204 & 204 & 204 \\
\hline \multicolumn{10}{|l|}{ U.S. } \\
\hline Mean & $16,371.4$ & 589.3 & 967.7 & 549.4 & $1,529.3$ & 604.4 & 82.2 & $1,345.6$ & $1,944.2$ \\
\hline Std. Dev. & $1,276.1$ & 241.8 & 54.5 & 65.3 & 27.9 & 37.1 & 32.4 & 125.3 & 121.2 \\
\hline Obs. & 204 & 204 & 204 & 204 & 204 & 204 & 204 & 204 & 204 \\
\hline \multicolumn{10}{|l|}{ California } \\
\hline Mean & $1,810.9$ & 121.2 & 79.9 & 42.7 & 166.3 & 71.1 & 7.4 & 100.7 & 165.6 \\
\hline Std. Dev. & 145.5 & 19.6 & 4.3 & 5.2 & 7.2 & 6.5 & 1.4 & 9.8 & 35.9 \\
\hline Obs. & 17 & 17 & 17 & 17 & 17 & 17 & 17 & 17 & 17 \\
\hline \multicolumn{10}{|l|}{ Arizona } \\
\hline Mean & 197.4 & 1.9 & 5.3 & 2.8 & 9.4 & 8.7 & 0.6 & 9.0 & n.a. \\
\hline Std. Dev. & 15.3 & 0.8 & 0.8 & 0.3 & 0.6 & 1.4 & 0.1 & 1.1 & n.a. \\
\hline Obs. & 17 & 17 & 17 & 17 & 17 & 17 & 17 & 17 & n.a. \\
\hline \multicolumn{10}{|l|}{ Texas } \\
\hline Mean & $1,025.1$ & 40.0 & 85.4 & 20.0 & 95.0 & 30.3 & 7.0 & 81.9 & 90.1 \\
\hline Std. Dev. & 61.0 & 18.9 & 5.3 & 2.6 & 2.6 & 4.8 & 1.2 & 5.4 & 5.2 \\
\hline Obs. & 17 & 17 & 17 & 17 & 17 & 17 & 17 & 17 & 17 \\
\hline \multicolumn{10}{|c|}{ Great Lakes } \\
\hline Mean & $3,851.5$ & 25.0 & 188.7 & 152.7 & 279.8 & 127.6 & 13.5 & 445.4 & n.a. \\
\hline Std. Dev. & 311.2 & 8.4 & 5.5 & 21.4 & 8.9 & 8.8 & 4.6 & 52.0 & n.a. \\
\hline Obs. & 17 & 17 & 17 & 17 & 17 & 17 & 17 & 17 & n.a. \\
\hline
\end{tabular}

Notes: Data in thousands. NAICS codes in parentheses. For maquiladora and U.S., data is monthly from January 1990 through December 2006 . For the U.S. states data is annual from 1990 through 2006

Sources: For maquiladora data the source is the Instituto Nacional de Estadistica, Geografia e Informatica. For U.S. data the source is the Bureau of Labor Statistics; and for U.S. state data the source is the Bureau of Economic Analysis 
Table 3. Production Worker Employment Summary Statistics

\begin{tabular}{|c|c|c|c|c|c|c|c|c|c|}
\hline & $\begin{array}{l}\text { Total } \\
\text { Mfg. }\end{array}$ & $\begin{array}{c}\text { Apparel } \\
\text { (315) }\end{array}$ & $\begin{array}{c}\text { Chemicals } \\
\text { (325) }\end{array}$ & $\begin{array}{c}\text { Electrical } \\
\text { equipment, } \\
\text { appliance and } \\
\text { components }(335)\end{array}$ & $\begin{array}{l}\text { Food } \\
(311)\end{array}$ & $\begin{array}{l}\text { Furniture and } \\
\text { related products } \\
(\mathbf{3 3 7})\end{array}$ & $\begin{array}{c}\text { Leather } \\
\text { (316) }\end{array}$ & $\begin{array}{c}\text { Machinery } \\
\text { (333) }\end{array}$ & $\begin{array}{c}\text { Transportation } \\
\text { equipment } \\
(336)\end{array}$ \\
\hline \multicolumn{10}{|l|}{ Mexico } \\
\hline Mean & $1,694.2$ & 134.7 & 15.0 & 230.9 & 8.5 & 36.4 & 6.1 & 9.4 & 147.3 \\
\hline Std. Dev. & 198.3 & 66.9 & 6.0 & 68.1 & 1.4 & 9.5 & 1.1 & 4.5 & 42.2 \\
\hline Obs. & 204 & 204 & 204 & 204 & 204 & 204 & 204 & 204 & 204 \\
\hline \multicolumn{10}{|l|}{$U . S}$. \\
\hline Mean & $11,744.3$ & 509.2 & 571.8 & 397.9 & $1,200.9$ & 476.2 & 68.5 & 885.6 & $1,406.2$ \\
\hline Std. Dev. & $1,021.5$ & 227.1 & 36.4 & 55.4 & 24.0 & 34.2 & 29.4 & 97.6 & 94.4 \\
\hline Obs. & 204 & 204 & 204 & 204 & 204 & 204 & 204 & 204 & 204 \\
\hline \multicolumn{10}{|l|}{ California } \\
\hline Mean & n.a. & n.a. & n.a. & n.a. & n.a. & n.a. & n.a. & n.a. & n.a. \\
\hline Std. Dev. & n.a. & n.a. & n.a. & n.a. & n.a. & n.a. & n.a. & n.a. & n.a. \\
\hline $\begin{array}{l}\text { Obs. } \\
\text { Arizona }\end{array}$ & \multicolumn{8}{|c|}{ Arizona } & n.a. \\
\hline Mean & n.a. & n.a. & n.a. & n.a. & n.a. & n.a. & n.a. & n.a. & n.a. \\
\hline Std. Dev. & n.a. & n.a. & n.a. & n.a. & n.a. & n.a. & n.a. & n.a. & n.a. \\
\hline $\begin{array}{l}\text { Obs. } \\
\text { Texas }\end{array}$ & \multicolumn{8}{|c|}{ Texas } & n.a. \\
\hline Mean & n.a. & n.a. & n.a. & n.a. & n.a. & n.a. & n.a. & n.a. & n.a. \\
\hline Std. Dev. & n.a. & n.a. & n.a. & n.a. & n.a. & n.a. & n.a. & n.a. & n.a. \\
\hline $\begin{array}{l}\text { Obs. } \\
\text { Great Lake }\end{array}$ & \multicolumn{8}{|c|}{ Great Lakes } & n.a. \\
\hline Mean & n.a. & n.a. & n.a. & n.a. & n.a. & n.a. & n.a. & n.a. & n.a. \\
\hline Std. Dev. & n.a. & n.a. & n.a. & n.a. & n.a. & n.a. & n.a. & n.a. & n.a. \\
\hline Obs. & n.a. & n.a. & n.a. & n.a. & n.a. & n.a. & n.a. & n.a. & n.a. \\
\hline
\end{tabular}

Notes: Data in thousands. NAICS codes in parentheses. For maquiladora and U.S., data is monthly from January 1990 through December 2006 . For the U.S. states data are not available.

Sources: For maquiladora data the source is the Instituto Nacional de Estadistica, Geografia e Informatica. For U.S. data the source is theBureau of Labor Statistics; and for U.S. state data the source is the Bureau of Economic Analysis. 
Table 4. Output Summary Statistics

\begin{tabular}{|c|c|c|c|c|c|c|c|c|c|}
\hline & $\begin{array}{l}\text { Total } \\
\text { Mfg. }\end{array}$ & $\begin{array}{c}\text { Apparel } \\
\text { (315) }\end{array}$ & $\begin{array}{c}\text { Chemicals } \\
\text { (325) }\end{array}$ & $\begin{array}{c}\text { Electrical } \\
\text { equipment, } \\
\text { appliance and } \\
\text { components (335) }\end{array}$ & $\begin{array}{l}\text { Food } \\
(311)\end{array}$ & $\begin{array}{l}\text { Furniture and } \\
\text { related products } \\
(\mathbf{3 3 7})\end{array}$ & $\begin{array}{c}\text { Leather } \\
\text { (316) }\end{array}$ & $\begin{array}{c}\text { Machinery } \\
\text { (333) }\end{array}$ & $\begin{array}{c}\text { Transportation } \\
\text { equipment } \\
(\mathbf{3 3 6 )}\end{array}$ \\
\hline \multicolumn{10}{|l|}{ Mexico } \\
\hline Mean & $144,606.9$ & $1,423.4$ & 276.0 & $4,041.9$ & 190.6 & 757.7 & 73.8 & 181.2 & $2,458.9$ \\
\hline Std. Dev. & $16,385.6$ & 809.4 & 143.4 & $1,671.1$ & 66.2 & 370.4 & 9.1 & 111.1 & 936.7 \\
\hline Obs. & 204 & 204 & 204 & 204 & 204 & 204 & 204 & 204 & 204 \\
\hline \multicolumn{10}{|l|}{ U.S. } \\
\hline Mean & 88.9 & 141.7 & 91.5 & 102.8 & 94.0 & 90.3 & 164.0 & 101.8 & 91.5 \\
\hline Std. Dev. & 16.2 & 39.0 & 10.5 & 10.5 & 7.4 & 12.0 & 45.2 & 11.8 & 11.9 \\
\hline Obs. & 204.0 & 204.0 & 204.0 & 204.0 & 204.0 & 204.0 & 204.0 & 204.0 & 204.0 \\
\hline \multicolumn{10}{|l|}{ California } \\
\hline Mean & 82.7 & 3.3 & 6.4 & 1.9 & 8.3 & 1.7 & n.a. & 4.6 & 7.4 \\
\hline Std. Dev. & 8.8 & 0.3 & 2.2 & 0.5 & 0.6 & 0.2 & n.a. & 0.9 & 1.4 \\
\hline \multicolumn{10}{|l|}{ Arizona } \\
\hline Mean & 10.6 & 0.1 & 0.3 & 0.1 & 0.5 & 0.2 & n.a. & 0.3 & 2.2 \\
\hline Std. Dev. & 1.7 & 0.0 & 0.1 & 0.0 & 0.1 & 0.1 & n.a. & 0.0 & 0.5 \\
\hline Obs. & 17 & 17 & 17 & 17 & 17 & 17 & n.a. & 17 & 17 \\
\hline \multicolumn{10}{|l|}{ Texas } \\
\hline Mean & 54.8 & 1.3 & 10.1 & 1.0 & 4.7 & 0.7 & n.a. & 4.0 & 4.1 \\
\hline Std. Dev. & 7.5 & 0.4 & 3.3 & 0.2 & 0.4 & 0.1 & n.a. & 1.0 & 0.6 \\
\hline Obs. & 17 & 17 & 17 & 17 & 17 & 17 & n.a. & 17 & 17 \\
\hline \multicolumn{10}{|c|}{ Great Lakes } \\
\hline Mean & 179.8 & 1.4 & 17.1 & 7.8 & 15.1 & 4.2 & n.a. & 18.8 & 39.3 \\
\hline Std. Dev. & 10.8 & 0.2 & 2.0 & 0.8 & 1.0 & 0.5 & n.a. & 2.0 & 5.1 \\
\hline Obs. & 17 & 17 & 17 & 17 & 17 & 17 & n.a. & 17 & 17 \\
\hline
\end{tabular}

Notes: For maquiladora and U.S., data are monthly from January 1990 through December 2006. For the U.S. states, data are annual from 1990 through 2006. Maquiladora data are in millions of real pesos (CPI 2002=100). U.S. national data corresponds to U.S. Industrial Production Index, $2002=100$. State level data are in billions of real dollars (Chained CPI 1982-84=100).

Sources: For maquiladora data the source is the Instituto Nacional de Estadistica, Geografia e Informatica. For U.S. data the source is the Federal Reserve Board and for U.S. states the data source is the Bureau of Economic Analysis 
Table 5. Volatility in Mexico and U.S. Offshoring Industries: Monthly Employment and Output

\begin{tabular}{|c|c|c|c|c|c|c|c|c|c|}
\hline & $\begin{array}{c}\text { Electrical Equipment, } \\
\text { Appliance, and Component } \\
\text { (335) }\end{array}$ & $\begin{array}{l}\text { Transportation } \\
\text { Equipment } \\
\text { (336) }\end{array}$ & $\begin{array}{c}\text { Apparel } \\
(315)\end{array}$ & $\begin{array}{l}\text { Leather and } \\
\text { Allied } \\
\text { Product } \\
(316) \\
\end{array}$ & $\begin{array}{l}\text { Furniture and } \\
\text { Related } \\
\text { Product (337) }\end{array}$ & $\begin{array}{c}\text { Chemical } \\
\text { (325) }\end{array}$ & $\begin{array}{l}\text { Machinery } \\
\quad(333)\end{array}$ & $\begin{array}{l}\text { Food } \\
(311)\end{array}$ & Average \\
\hline \multicolumn{10}{|l|}{ TOTAL EMPLOYMENT } \\
\hline$\sigma\left(\mathrm{Y}_{\mathrm{i}}^{\mathrm{MX}}\right)$ & 0.33 & 0.31 & 0.63 & 0.18 & 0.30 & 0.48 & 0.52 & 0.16 & 0.36 \\
\hline$\sigma\left(\mathrm{Y}_{\mathrm{i}}^{\mathrm{US}}\right)$ & 0.13 & 0.06 & 0.47 & 0.43 & 0.06 & 0.06 & 0.10 & 0.02 & 0.17 \\
\hline$\sigma\left(\mathrm{Y}^{\mathrm{MX}}\right)$ & 0.11 & 0.11 & 0.11 & 0.11 & 0.11 & 0.11 & 0.11 & 0.11 & 0.11 \\
\hline$\sigma\left(\mathrm{Y}^{\mathrm{US}}\right)$ & 0.08 & 0.08 & 0.08 & 0.08 & 0.08 & 0.08 & 0.08 & 0.08 & 0.08 \\
\hline$\sigma\left(\mathrm{Y}_{\mathrm{i}}^{\mathrm{MX}}\right) / \sigma\left(\mathrm{Y}_{\mathrm{i}}^{\mathrm{US}}\right)$ & 2.58 & 5.01 & 1.34 & 0.42 & 4.94 & 8.39 & 5.48 & 8.69 & 2.20 \\
\hline$\sigma\left(\mathrm{Y}^{\mathrm{MX}}\right) / \sigma\left(\mathrm{Y}^{\mathrm{US}}\right)$ & 1.34 & 1.34 & 1.34 & 1.34 & 1.34 & 1.34 & 1.34 & 1.34 & 1.34 \\
\hline$\frac{\sigma\left(\mathrm{Y}_{\mathrm{i}}^{\mathrm{MX}}\right) / \sigma\left(\mathrm{Y}_{\mathrm{i}}^{\mathrm{US}}\right)}{\sigma\left(\mathrm{Y}^{\mathrm{MX}}\right) / \sigma\left(\mathrm{Y}^{\mathrm{US}}\right)}$ & 1.93 & 3.75 & 1.00 & 0.32 & 3.70 & 6.28 & 4.10 & 6.51 & 1.65 \\
\hline \multicolumn{10}{|c|}{ PRODUCTION WORKER EMPLOYMENT } \\
\hline$\sigma\left(\mathrm{Y}_{\mathrm{i}}^{\mathrm{MX}}\right)$ & 0.32 & 0.31 & 0.63 & 0.19 & 0.29 & 0.45 & 0.52 & 0.17 & 0.36 \\
\hline$\sigma\left(\mathrm{Y}_{\mathrm{i}}^{\mathrm{US}}\right)$ & 0.15 & 0.07 & 0.52 & 0.47 & 0.07 & 0.07 & 0.11 & 0.02 & 0.18 \\
\hline$\sigma\left(Y^{\mathrm{MX}}\right)$ & 0.12 & 0.12 & 0.12 & 0.12 & 0.12 & 0.12 & 0.12 & 0.12 & 0.12 \\
\hline$\sigma\left(\mathrm{Y}^{\mathrm{US}}\right)$ & 0.09 & 0.09 & 0.09 & 0.09 & 0.09 & 0.09 & 0.09 & 0.09 & 0.09 \\
\hline$\sigma\left(\mathrm{Y}_{\mathrm{i}}^{\mathrm{MX}}\right) / \sigma\left(\mathrm{Y}_{\mathrm{i}}^{\mathrm{US}}\right)$ & 2.14 & 4.53 & 1.20 & 0.40 & 4.06 & 6.85 & 4.58 & 8.33 & 1.93 \\
\hline$\sigma\left(\mathrm{Y}^{\mathrm{MX}}\right) / \sigma\left(\mathrm{Y}^{\mathrm{US}}\right)$ & 1.29 & 1.29 & 1.29 & 1.29 & 1.29 & 1.29 & 1.29 & 1.29 & 1.29 \\
\hline$\frac{\sigma\left(\mathrm{Y}_{\mathrm{i}}^{\mathrm{MX}}\right) / \sigma\left(\mathrm{Y}_{\mathrm{i}}^{\mathrm{US}}\right)}{\sigma\left(\mathrm{Y}^{\mathrm{MX}}\right) / \sigma\left(\mathrm{Y}^{\mathrm{US}}\right)}$ & 1.66 & 3.52 & 0.93 & 0.31 & 3.15 & 5.31 & 3.55 & 6.46 & 1.50 \\
\hline \multicolumn{10}{|l|}{ OUTPUT } \\
\hline$\sigma\left(\mathrm{Y}_{\mathrm{i}}^{\mathrm{MX}}\right)$ & 0.47 & 0.38 & 0.78 & 0.12 & 0.55 & 0.58 & 0.63 & 0.31 & 0.48 \\
\hline$\sigma\left(\mathrm{Y}_{\mathrm{i}}^{\mathrm{US}}\right)$ & 0.10 & 0.13 & 0.32 & 0.31 & 0.14 & 0.11 & 0.12 & 0.08 & 0.16 \\
\hline$\sigma\left(\mathrm{Y}^{\mathrm{MX}}\right)$ & 0.11 & 0.11 & 0.11 & 0.11 & 0.11 & 0.11 & 0.11 & 0.11 & 0.11 \\
\hline$\sigma\left(\mathrm{Y}^{\mathrm{US}}\right)$ & 0.19 & 0.19 & 0.19 & 0.19 & 0.19 & 0.19 & 0.19 & 0.19 & 0.19 \\
\hline$\sigma\left(\mathrm{Y}_{\mathrm{i}}^{\mathrm{MX}}\right) / \sigma\left(\mathrm{Y}_{\mathrm{i}}^{\mathrm{US}}\right)$ & 4.54 & 2.89 & 2.43 & 0.39 & 3.99 & 5.13 & 5.27 & 4.01 & 2.91 \\
\hline$\sigma\left(\mathrm{Y}^{\mathrm{MX}}\right) / \sigma\left(\mathrm{Y}^{\mathrm{US}}\right)$ & 0.60 & 0.60 & 0.60 & 0.60 & 0.60 & 0.60 & 0.60 & 0.60 & 0.60 \\
\hline$\frac{\sigma\left(\mathrm{Y}_{\mathrm{i}}^{\mathrm{MX}}\right) / \sigma\left(\mathrm{Y}_{\mathrm{i}}^{\mathrm{US}}\right)}{\sigma\left(\mathrm{Y}^{\mathrm{MX}}\right) / \sigma\left(\mathrm{Y}^{\mathrm{US}}\right)}$ & 7.51 & 4.78 & 4.02 & 0.65 & 6.61 & 8.48 & 8.71 & 6.63 & 4.82 \\
\hline $\begin{array}{ll}\text { Notes: } & \text { The top } \\
& \text { employr } \\
& \text { and stan } \\
& \text { and seas }\end{array}$ & $\begin{array}{l}\text { the table reports standard de } \\
\text { ata are monthly and seasonal }\end{array}$ & $\begin{array}{l}\text { tons and standa } \\
\text { adjusted from Ja }\end{array}$ & eviation & $\begin{array}{l}\text { ios for both t } \\
\text { ough Decemt }\end{array}$ & and productiol & $\begin{array}{l}\text { orker emp } \\
\text { nalf of the }\end{array}$ & $\begin{array}{l}\text { ment. Eacl } \\
\text { le reports s } \\
\text { for the U.S }\end{array}$ & $\begin{array}{l}\text { ries is } \\
\text { dard d }\end{array}$ & $\begin{array}{l}\text { tions } \\
\text { ionthly }\end{array}$ \\
\hline
\end{tabular}


Table 6. Volatility in Mexico and Texas Offshoring Industries: Annual Employment and Output

\begin{tabular}{cccccccc} 
Electrical Equipment, & Transportation & Leather and & Furniture & & \\
Appliance, and & Equipment & Apparel & Allied & and Related & Chemical & Machinery & Food \\
Component & $(336)$ & $(315)$ & Product & Product & $(325)$ & $(333)$ & $(311)$ \\
$(335)$ & & & $(316)$ & $(337)$ & & & \\
\hline
\end{tabular}

TOTAL EMPLOYMENT

$\underline{\text { Standard Deviations }}$

\begin{tabular}{|c|c|c|c|c|c|c|c|c|c|}
\hline$\sigma\left(\mathrm{Y}_{\mathrm{i}}^{\mathrm{MX}}\right)$ & 0.32 & 0.31 & 0.63 & 0.18 & 0.30 & 0.48 & 0.52 & 0.14 & 0.36 \\
\hline$\sigma\left(\mathrm{Y}_{\mathrm{i}}^{\mathrm{TX}}\right)$ & 0.13 & 0.06 & 0.60 & 0.17 & 0.16 & 0.06 & 0.06 & 0.03 & 0.16 \\
\hline$\sigma\left(\mathrm{Y}^{\mathrm{MX}}\right)$ & 0.11 & 0.11 & 0.11 & 0.11 & 0.11 & 0.11 & 0.11 & 0.11 & 0.11 \\
\hline$\sigma\left(\mathrm{Y}^{\mathrm{TX}}\right)$ & 0.06 & 0.06 & 0.06 & 0.06 & 0.06 & 0.06 & 0.06 & 0.06 & 0.06 \\
\hline$\sigma\left(\mathrm{Y}_{\mathrm{i}}^{\mathrm{MX}}\right) / \sigma\left(\mathrm{Y}_{\mathrm{i}}^{\mathrm{TX}}\right)$ & 2.56 & 5.65 & 1.05 & 1.07 & 1.82 & 7.79 & 8.06 & 5.24 & 4.15 \\
\hline$\sigma\left(\mathrm{Y}^{\mathrm{MX}}\right) / \sigma\left(\mathrm{Y}^{\mathrm{TX}}\right)$ & 1.85 & 1.85 & 1.85 & 1.85 & 1.85 & 1.85 & 1.85 & 1.85 & 1.85 \\
\hline$\sigma\left(\mathrm{Y}_{\mathrm{i}}^{\mathrm{MX}}\right) / \sigma\left(\mathrm{Y}_{\mathrm{i}}^{\mathrm{TX}}\right)$ & 1.38 & 3.06 & 0.57 & 0.58 & 0.98 & 4.21 & 4.36 & 2.84 & 2.25 \\
\hline
\end{tabular}

OUTPUT

$\underline{\text { Standard Deviations }}$

\begin{tabular}{|c|c|c|c|c|c|c|c|c|c|}
\hline$\sigma\left(Y_{\mathrm{i}}^{\mathrm{MX}}\right)$ & 0.46 & 0.38 & 0.77 & 0.10 & 0.54 & 0.58 & 0.63 & 0.28 & 0.47 \\
\hline$\sigma\left(\mathrm{Y}_{\mathrm{i}}^{\mathrm{TX}}\right)$ & 0.19 & 0.14 & 0.38 & n.a. & 0.17 & 0.28 & 0.24 & 0.08 & 0.21 \\
\hline$\sigma\left(\mathrm{Y}^{\mathrm{MX}}\right)$ & 0.11 & 0.11 & 0.11 & 0.11 & 0.11 & 0.11 & 0.11 & 0.11 & 0.11 \\
\hline$\sigma\left(\mathrm{Y}^{\mathrm{TX}}\right)$ & 0.13 & 0.13 & 0.13 & 0.13 & 0.13 & 0.13 & 0.13 & 0.13 & 0.13 \\
\hline$\sigma\left(\mathrm{Y}_{\mathrm{i}}^{\mathrm{MX}}\right) / \sigma\left(\mathrm{Y}_{\mathrm{i}}^{\mathrm{TX}}\right)$ & 2.45 & 2.73 & 2.03 & n.a. & 3.14 & 2.06 & 2.61 & 3.60 & 2.66 \\
\hline$\sigma\left(\mathrm{Y}^{\mathrm{MX}}\right) / \sigma\left(\mathrm{Y}^{\mathrm{TX}}\right)$ & 0.86 & 0.86 & 0.86 & 0.86 & 0.86 & 0.86 & 0.86 & 0.86 & 0.86 \\
\hline$\sigma\left(\mathrm{Y}_{\mathrm{i}}^{\mathrm{MX}}\right) / \sigma\left(\mathrm{Y}_{\mathrm{i}}^{\mathrm{TX}}\right)$ & 2.86 & 3.19 & 2.38 & n.a. & 3.68 & 2.41 & 3.05 & 4.21 & 3.11 \\
\hline
\end{tabular}

Notes: $\quad$ The top half of the table reports standard deviations and standard deviation ratios for employment. Each series is log employment. Data are annual from 1990 through 2006. The bottom half of the table reports standard deviations and standard deviation ratios for output. Each series is $\log$ output, measured by real pesos for Mexico and real dollars for Texas. 
Table 7. Volatility in Mexico and California Offshoring Industries: Annual Employment and Output

\begin{tabular}{cccccccc} 
Electrical Equipment, & Transportation & Leather and & Furniture & & \\
Appliance, and & Equipment & Apparel & Allied & and Related & Chemical & Machinery & Food \\
Component & $(336)$ & $(315)$ & Product & Product & $(325)$ & $(333)$ & $(311)$ \\
$(335)$ & & & $(316)$ & $(337)$ & & & \\
\hline
\end{tabular}

TOTAL EMPLOYMENT

$\underline{\text { Standard Deviations }}$

\begin{tabular}{|c|c|c|c|c|c|c|c|c|c|}
\hline$\sigma\left(\mathrm{Y}_{\mathrm{i}}^{\mathrm{MX}}\right)$ & 0.32 & 0.31 & 0.63 & 0.18 & 0.30 & 0.48 & 0.52 & 0.14 & 0.36 \\
\hline$\sigma\left(Y_{i}^{C A}\right)$ & 0.12 & 0.20 & 0.17 & 0.20 & 0.09 & 0.05 & 0.10 & 0.04 & 0.12 \\
\hline$\sigma\left(\mathrm{Y}^{\mathrm{MX}}\right)$ & 0.11 & 0.11 & 0.11 & 0.11 & 0.11 & 0.11 & 0.11 & 0.11 & 0.11 \\
\hline$\sigma\left(\mathrm{Y}^{\mathrm{CA}}\right)$ & 0.08 & 0.08 & 0.08 & 0.08 & 0.08 & 0.08 & 0.08 & 0.08 & 0.08 \\
\hline$\sigma\left(\mathrm{Y}_{\mathrm{i}}^{\mathrm{MX}}\right) / \sigma\left(\mathrm{Y}_{\mathrm{i}}^{\mathrm{CA}}\right)$ & 2.76 & 1.60 & 3.76 & 0.88 & 3.38 & 9.14 & 5.42 & 3.47 & 3.80 \\
\hline$\sigma\left(\mathrm{Y}^{\mathrm{MX}}\right) / \sigma\left(\mathrm{Y}^{\mathrm{CA}}\right)$ & 1.35 & 1.35 & 1.35 & 1.35 & 1.35 & 1.35 & 1.35 & 1.35 & 1.35 \\
\hline$\sigma\left(\mathrm{Y}_{\mathrm{i}}^{\mathrm{MX}}\right) / \sigma\left(\mathrm{Y}_{\mathrm{i}}^{\mathrm{CA}}\right)$ & 2.05 & 1.19 & 2.79 & 0.66 & 2.51 & 6.79 & 4.02 & 2.57 & 2.82 \\
\hline
\end{tabular}

OUTPUT

$\underline{\text { Standard Deviations }}$

\begin{tabular}{|c|c|c|c|c|c|c|c|c|c|}
\hline$\sigma\left(\mathrm{Y}_{\mathrm{i}}^{\mathrm{MX}}\right)$ & 0.46 & 0.38 & 0.77 & 0.10 & 0.54 & 0.58 & 0.63 & 0.28 & 0.47 \\
\hline$\sigma\left(Y_{i}^{C A}\right)$ & 0.21 & 0.17 & 0.08 & n.a. & 0.13 & 0.31 & 0.17 & 0.07 & 0.16 \\
\hline$\sigma\left(\mathrm{Y}^{\mathrm{MX}}\right)$ & 0.11 & 0.11 & 0.11 & 0.11 & 0.11 & 0.11 & 0.11 & 0.11 & 0.11 \\
\hline$\sigma\left(Y^{\mathrm{CA}}\right)$ & 0.10 & 0.10 & 0.10 & 0.10 & 0.10 & 0.10 & 0.10 & 0.10 & 0.10 \\
\hline$\sigma\left(\mathrm{Y}_{\mathrm{i}}^{\mathrm{MX}}\right) / \sigma\left(\mathrm{Y}_{\mathrm{i}}^{\mathrm{CA}}\right)$ & 2.22 & 2.21 & 9.16 & n.a. & 4.23 & 1.87 & 3.60 & 4.22 & 3.93 \\
\hline$\sigma\left(\mathrm{Y}^{\mathrm{MX}}\right) / \sigma\left(\mathrm{Y}^{\mathrm{CA}}\right)$ & 1.13 & 1.13 & 1.13 & 1.13 & 1.13 & 1.13 & 1.13 & 1.13 & 1.13 \\
\hline$\sigma\left(\mathrm{Y}_{\mathrm{i}}^{\mathrm{MX}}\right) / \sigma\left(\mathrm{Y}_{\mathrm{i}}^{\mathrm{CA}}\right)$ & 1.96 & 1.95 & 8.09 & n.a. & 3.73 & 1.65 & 3.18 & 3.72 & 3.47 \\
\hline
\end{tabular}

Notes: $\quad$ The top half of the table reports standard deviations and standard deviation ratios for employment. Each series is log employment. Data are annual from 1990 through 2006. The bottom half of the table reports standard deviations and standard deviation ratios for output. Each series is log output, measured by real pesos for Mexico and real dollars for California. 
Table 8. Volatility in Mexico and Arizona Offshoring Industries: Annual Employment and Output

\begin{tabular}{cccccccc} 
Electrical Equipment, & Transportation & Leather and & Furniture & & \\
Appliance, and & Equipment & Apparel & Allied & and Related & Chemical & Machinery & Food \\
Component & $(336)$ & $(315)$ & Product & Product & $(325)$ & $(333)$ & $(311)$ \\
$(335)$ & & & $(316)$ & $(337)$ & & & \\
\hline
\end{tabular}

TOTAL EMPLOYMENT

$\underline{\text { Standard Deviations }}$

\begin{tabular}{cc}
$\sigma\left(\mathrm{Y}_{\mathrm{i}}^{\mathrm{MX}}\right)$ & 0.32 \\
$\sigma\left(\mathrm{Y}_{\mathrm{i}}^{\mathrm{AZ}}\right)$ & 0.10 \\
$\sigma\left(\mathrm{Y}^{\mathrm{MX}}\right)$ & 0.11 \\
$\sigma\left(\mathrm{Y}^{\mathrm{AZ}}\right)$ & 0.07 \\
$\sigma\left(\mathrm{Y}_{\mathrm{i}}^{\mathrm{MX}}\right) / \sigma\left(\mathrm{Y}_{\mathrm{i}}^{\mathrm{AZ}}\right)$ & 3.19 \\
$\sigma\left(\mathrm{Y}^{\mathrm{MX}}\right) / \sigma\left(\mathrm{Y}^{\mathrm{AZ}}\right)$ & 1.42 \\
$\sigma\left(\mathrm{Y}_{\mathrm{i}}^{\mathrm{MX}}\right) / \sigma\left(\mathrm{Y}_{\mathrm{i}}^{\mathrm{AZ}}\right)$ & 2.25 \\
\hline$\sigma\left(\mathrm{Y}^{\mathrm{MX}}\right) / \sigma\left(\mathrm{Y}^{\mathrm{AZ}}\right)$ &
\end{tabular}

OUTPUT

$\underline{\text { Standard Deviations }}$

\begin{tabular}{|c|c|c|c|c|c|c|c|c|c|}
\hline$\sigma\left(\mathrm{Y}_{\mathrm{i}}^{\mathrm{MX}}\right)$ & 0.46 & 0.38 & 0.77 & 0.10 & 0.54 & 0.58 & 0.63 & 0.28 & 0.47 \\
\hline$\sigma\left(\mathrm{Y}_{\mathrm{i}}^{\mathrm{AZ}}\right)$ & 0.31 & 0.20 & 0.08 & n.a. & 0.33 & 0.33 & 0.11 & 0.11 & 0.21 \\
\hline$\sigma\left(\mathrm{Y}^{\mathrm{MX}}\right)$ & 0.11 & 0.11 & 0.11 & 0.11 & 0.11 & 0.11 & 0.11 & 0.11 & 0.11 \\
\hline$\sigma\left(Y^{A Z}\right)$ & 0.16 & 0.16 & 0.16 & 0.16 & 0.16 & 0.16 & 0.16 & 0.16 & 0.16 \\
\hline$\sigma\left(\mathrm{Y}_{\mathrm{i}}^{\mathrm{MX}}\right) / \sigma\left(\mathrm{Y}_{\mathrm{i}}^{\mathrm{AZ}}\right)$ & 1.50 & 1.94 & 9.30 & n.a. & 1.65 & 1.78 & 5.72 & 2.45 & 3.48 \\
\hline$\sigma\left(\mathrm{Y}^{\mathrm{MX}}\right) / \sigma\left(\mathrm{Y}^{\mathrm{AZ}}\right)$ & 0.67 & 0.67 & 0.67 & 0.67 & 0.67 & 0.67 & 0.67 & 0.67 & 0.67 \\
\hline$\sigma\left(\mathrm{Y}_{\mathrm{i}}^{\mathrm{MX}}\right) / \sigma\left(\mathrm{Y}_{\mathrm{i}}^{\mathrm{AZ}}\right)$ & 2.23 & 2.88 & 13.83 & n.a. & 2.46 & 2.64 & 8.50 & 3.65 & 5.17 \\
\hline
\end{tabular}

Notes: $\quad$ The top half of the table reports standard deviations and standard deviation ratios for employment. Each series is log employment. Data are annual from 1990 through 2006. The bottom half of the table reports standard deviations and standard deviation ratios for output. Each series is $\log$ output, measured by real pesos for Mexico and real dollars for Arizona. 
Table 9. Volatility in Mexico and Great Lakes Offshoring Industries: Annual Employment and Output

\begin{tabular}{cccccccc}
\hline Electrical Equipment, & Transportation & Leather and & Furniture & & \\
Appliance, and & Equipment & Apparel & Allied & and Related & Chemical & Machinery & Food \\
Component & $(336)$ & $(315)$ & Product & Product & $(325)$ & $(333)$ & $(311)$ \\
$(335)$ & & $(316)$ & $(337)$ & & & \\
\hline \hline
\end{tabular}

TOTAL EMPLOYMENT

$\underline{\text { Standard Deviations }}$

\begin{tabular}{cc}
$\sigma\left(\mathrm{Y}_{\mathrm{i}}^{\mathrm{MX}}\right)$ & 0.32 \\
$\sigma\left(\mathrm{Y}_{\mathrm{i}}^{\mathrm{GL}}\right)$ & 0.15 \\
$\sigma\left(\mathrm{Y}^{\mathrm{MX}}\right)$ & 0.11 \\
$\sigma\left(\mathrm{Y}^{\mathrm{GL}}\right)$ & 0.08 \\
$\sigma\left(\mathrm{Y}_{\mathrm{i}}^{\mathrm{MX}}\right) / \sigma\left(\mathrm{Y}_{\mathrm{i}}^{\mathrm{GL}}\right)$ & 2.21 \\
$\sigma\left(\mathrm{Y}^{\mathrm{MX}}\right) / \sigma\left(\mathrm{Y}^{\mathrm{GL}}\right)$ & 1.32 \\
$\sigma\left(\mathrm{Y}_{\mathrm{i}}^{\mathrm{MX}}\right) / \sigma\left(\mathrm{Y}_{\mathrm{i}}^{\mathrm{GL}}\right)$ & 1.68 \\
\hline$\sigma\left(\mathrm{Y}^{\mathrm{MX}}\right) / \sigma\left(\mathrm{Y}^{\mathrm{GL}}\right)$ &
\end{tabular}

OUTPUT

$\underline{\text { Standard Deviations }}$

\begin{tabular}{|c|c|c|c|c|c|c|c|c|c|}
\hline$\sigma\left(\mathrm{Y}_{\mathrm{i}}^{\mathrm{MX}}\right)$ & 0.46 & 0.38 & 0.77 & 0.10 & 0.54 & 0.58 & 0.63 & 0.28 & 0.47 \\
\hline$\sigma\left(\mathrm{Y}_{\mathrm{i}}^{\mathrm{GL}}\right)$ & 0.09 & 0.13 & 0.13 & n.a. & 0.12 & 0.11 & 0.10 & 0.07 & 0.11 \\
\hline$\sigma\left(\mathrm{Y}^{\mathrm{MX}}\right)$ & 0.11 & 0.11 & 0.11 & 0.11 & 0.11 & 0.11 & 0.11 & 0.11 & 0.11 \\
\hline$\sigma\left(Y^{\mathrm{GL}}\right)$ & 0.06 & 0.06 & 0.06 & 0.06 & 0.06 & 0.06 & 0.06 & 0.06 & 0.06 \\
\hline$\sigma\left(\mathrm{Y}_{\mathrm{i}}^{\mathrm{MX}}\right) / \sigma\left(\mathrm{Y}_{\mathrm{i}}^{\mathrm{GL}}\right)$ & 5.02 & 2.83 & 5.88 & n.a. & 4.43 & 5.14 & 6.11 & 3.94 & 4.76 \\
\hline$\sigma\left(\mathrm{Y}^{\mathrm{MX}}\right) / \sigma\left(\mathrm{Y}^{\mathrm{GL}}\right)$ & 1.88 & 1.88 & 1.88 & 1.88 & 1.88 & 1.88 & 1.88 & 1.88 & 1.88 \\
\hline$\sigma\left(Y_{i}^{\mathrm{MX}}\right) / \sigma\left(Y_{i}^{\mathrm{GL}}\right)$ & 2.67 & 1.50 & 3.12 & n.a. & 2.35 & 2.73 & 3.24 & 2.09 & 2.53 \\
\hline
\end{tabular}

Notes: $\quad$ The top half of the table reports standard deviations and standard deviation ratios for employment. Each series is log employment. Data are annual from 1990 through 2006. The bottom half of the table reports standard deviations and standard deviation ratios for output. Each series is log output, measured by real pesos for Mexico and real dollars for the Great Lakes region. 
Table 10. Correlation Coefficients for Mexico and U.S. Offshoring Industries: Monthly Employment and Output

\begin{tabular}{|c|c|c|c|c|c|c|c|c|c|}
\hline & $\begin{array}{c}\text { Electrical Equipment, } \\
\text { Appliance, and } \\
\text { Component } \\
(335) \\
\end{array}$ & $\begin{array}{l}\text { Transportation } \\
\text { Equipment } \\
\text { (336) }\end{array}$ & $\begin{array}{c}\text { Apparel } \\
(315)\end{array}$ & $\begin{array}{l}\text { Leather and } \\
\text { Allied Product } \\
\quad(316)\end{array}$ & $\begin{array}{l}\text { Furniture and } \\
\text { Related } \\
\text { Product (337) }\end{array}$ & $\begin{array}{c}\text { Chemical } \\
(325)\end{array}$ & $\begin{array}{c}\text { Machinery } \\
\text { (333) }\end{array}$ & $\begin{array}{l}\text { Food } \\
(311)\end{array}$ & Average \\
\hline \multicolumn{10}{|c|}{ TOTAL EMPLOYMENT } \\
\hline $\operatorname{corr}\left(\mathrm{Y}_{\mathrm{i}}^{\mathrm{MX}}, \mathrm{Y}_{\mathrm{i}}^{\mathrm{US}}\right)$ & -0.49 & -0.57 & -0.72 & 0.61 & 0.38 & -0.83 & -0.53 & -0.01 & -0.27 \\
\hline $\operatorname{corr}\left(\mathrm{Y}^{\mathrm{MX}}, \mathrm{Y}^{\mathrm{US}}\right)$ & -0.28 & -0.28 & -0.28 & -0.28 & -0.28 & -0.28 & -0.28 & -0.28 & -0.28 \\
\hline $\operatorname{corr}\left(\mathrm{Y}_{\mathrm{i}}^{\mathrm{MX}}, \mathrm{Y}^{\mathrm{MX}}\right)$ & 0.87 & 0.82 & 0.83 & 0.07 & 0.84 & 0.77 & 0.78 & 0.47 & 0.68 \\
\hline $\operatorname{corr}\left(\mathrm{Y}_{\mathrm{i}}^{\mathrm{US}}, \mathrm{Y}^{\mathrm{US}}\right)$ & 1.00 & 0.95 & 0.89 & 0.87 & 0.56 & 0.93 & 0.95 & 0.76 & 0.86 \\
\hline \multicolumn{10}{|c|}{ PRODUCTION WORKER EMPLOYMENT } \\
\hline $\operatorname{corr}\left(\mathrm{Y}_{\mathrm{i}}^{\mathrm{MX}}, \mathrm{Y}_{\mathrm{i}}^{\mathrm{US}}\right)$ & -0.46 & -0.39 & -0.71 & 0.55 & 0.32 & -0.71 & -0.55 & 0.31 & -0.21 \\
\hline $\operatorname{corr}\left(\mathrm{Y}^{\mathrm{MX}}, \mathrm{Y}^{\mathrm{US}}\right)$ & -0.26 & -0.26 & -0.26 & -0.26 & -0.26 & -0.26 & -0.26 & -0.26 & -0.26 \\
\hline $\operatorname{corr}\left(\mathrm{Y}_{\mathrm{i}}^{\mathrm{MX}}, \mathrm{Y}^{\mathrm{MX}}\right)$ & 0.89 & 0.82 & 0.85 & 0.16 & 0.84 & 0.77 & 0.77 & 0.36 & 0.68 \\
\hline $\operatorname{corr}\left(\mathrm{Y}_{\mathrm{i}}^{\mathrm{US}}, \mathrm{Y}^{\mathrm{US}}\right)$ & 0.99 & 0.93 & 0.89 & 0.85 & 0.63 & 0.98 & 0.97 & 0.55 & 0.85 \\
\hline \multicolumn{10}{|l|}{ OUTPUT } \\
\hline $\operatorname{corr}\left(\mathrm{Y}_{\mathrm{i}}^{\mathrm{MX}}, \mathrm{Y}_{\mathrm{i}}^{\mathrm{US}}\right)$ & 0.65 & 0.93 & -0.63 & -0.15 & 0.95 & 0.94 & 0.67 & 0.82 & 0.52 \\
\hline $\operatorname{corr}\left(\mathrm{Y}^{\mathrm{MX}}, \mathrm{Y}^{\mathrm{US}}\right)$ & 0.91 & 0.91 & 0.91 & 0.91 & 0.91 & 0.91 & 0.91 & 0.91 & 0.91 \\
\hline $\operatorname{corr}\left(\mathrm{Y}_{\mathrm{i}}^{\mathrm{MX}}, \mathrm{Y}^{\mathrm{MX}}\right)$ & 0.91 & 0.87 & 0.85 & 0.26 & 0.88 & 0.90 & 0.87 & 0.77 & 0.79 \\
\hline $\operatorname{corr}\left(\mathrm{Y}_{\mathrm{i}}^{\mathrm{US}}, \mathrm{Y}^{\mathrm{US}}\right)$ & 0.66 & 0.97 & -0.75 & -0.79 & 0.99 & 0.96 & 0.84 & 0.96 & 0.48 \\
\hline
\end{tabular}

Notes: The table above shows correlation coefficients. For data details see Table 5. 
Table 11. Correlation Coefficients for Mexico and Texas Offshoring Industries: Annual Employment and Output

\begin{tabular}{|c|c|c|c|c|c|c|c|c|}
\hline $\begin{array}{c}\text { Electrical } \\
\text { Equipment, } \\
\text { Appliance, and } \\
\text { Component } \\
\text { (335) }\end{array}$ & $\begin{array}{l}\text { Transportation } \\
\text { Equipment } \\
\text { (336) }\end{array}$ & $\begin{array}{c}\text { Apparel } \\
(315)\end{array}$ & $\begin{array}{l}\text { Leather } \\
\text { and } \\
\text { Allied } \\
\text { Product } \\
(316)\end{array}$ & $\begin{array}{l}\text { Furniture } \\
\text { and } \\
\text { Related } \\
\text { Product } \\
\text { (337) }\end{array}$ & $\begin{array}{c}\text { Chemical } \\
(325)\end{array}$ & $\begin{array}{l}\text { Machinery } \\
\text { (333) }\end{array}$ & $\begin{array}{l}\text { Food } \\
(311)\end{array}$ & Average \\
\hline
\end{tabular}

\begin{tabular}{|c|c|c|c|c|c|c|c|c|c|}
\hline \multicolumn{10}{|c|}{ TOTAL EMPLOYMENT } \\
\hline \multicolumn{10}{|c|}{$\underline{\text { Correlations }}$} \\
\hline $\operatorname{corr}\left(\mathrm{Y}_{\mathrm{i}}^{\mathrm{MX}}, \mathrm{Y}_{\mathrm{i}}^{\mathrm{US}}\right)$ & 0.92 & -0.32 & -0.65 & 0.74 & 1.05 & -0.61 & 0.87 & 0.44 & 0.30 \\
\hline $\operatorname{corr}\left(\mathrm{Y}^{\mathrm{MX}}, \mathrm{Y}^{\mathrm{US}}\right)$ & 0.25 & 0.25 & 0.25 & 0.25 & 0.25 & 0.25 & 0.25 & 0.25 & 0.25 \\
\hline $\operatorname{corr}\left(\mathrm{Y}_{\mathrm{i}}^{\mathrm{MX}}, \mathrm{Y}^{\mathrm{MX}}\right)$ & 0.93 & 0.88 & 0.88 & 0.07 & 0.89 & 0.82 & 0.84 & 0.54 & 0.73 \\
\hline $\operatorname{corr}\left(\mathrm{Y}_{\mathrm{i}}^{\mathrm{TX}}, \mathrm{Y}^{\mathrm{TX}}\right)$ & 0.71 & 0.04 & 0.55 & 0.57 & 0.24 & 0.80 & 0.38 & 0.38 & 0.46 \\
\hline
\end{tabular}

OUTPUT

Correlations

\begin{tabular}{llllllllll}
$\operatorname{corr}\left(\mathrm{Y}_{\mathrm{i}}^{\mathrm{MX}}, \mathrm{Y}_{\mathrm{i}}^{\mathrm{US}}\right)$ & 0.86 & 0.75 & -0.60 & n.a. & 1.00 & 0.55 & 0.79 & 0.66 & 0.57 \\
$\operatorname{corr}\left(\mathrm{Y}^{\mathrm{MX}}, \mathrm{Y}^{\mathrm{US}}\right)$ & 0.84 & 0.84 & 0.84 & 0.84 & 0.84 & 0.84 & 0.84 & 0.84 & 0.84 \\
$\operatorname{corr}\left(\mathrm{Y}_{\mathrm{i}}^{\mathrm{MX}}, \mathrm{Y}^{\mathrm{MX}}\right)$ & 0.99 & 0.94 & 0.93 & 0.29 & 0.96 & 0.98 & 0.95 & 0.91 & 0.87 \\
$\operatorname{corr}\left(\mathrm{Y}_{\mathrm{i}}^{\mathrm{TX}}, \mathrm{Y}^{\mathrm{TX}}\right)$ & 0.78 & 0.18 & -0.68 & n.a. & 0.77 & 1.00 & 1.00 & 0.55 & 0.51 \\
\hline
\end{tabular}

Notes: The table above shows correlation coefficients. For data details see Table 6 . 
Table 12. Correlation Coefficients for Mexico and California Offshoring Industries: Annual Employment and Output

\begin{tabular}{|c|c|c|c|c|c|c|c|c|}
\hline $\begin{array}{c}\text { Electrical } \\
\text { Equipment, } \\
\text { Appliance, and } \\
\text { Component } \\
\text { (335) }\end{array}$ & $\begin{array}{l}\text { Transportation } \\
\text { Equipment } \\
\text { (336) }\end{array}$ & $\begin{array}{c}\text { Apparel } \\
(315)\end{array}$ & $\begin{array}{l}\text { Leather } \\
\text { and } \\
\text { Allied } \\
\text { Product } \\
(316)\end{array}$ & $\begin{array}{c}\text { Furniture } \\
\text { and } \\
\text { Related } \\
\text { Product } \\
\text { (337) }\end{array}$ & $\begin{array}{c}\text { Chemical } \\
(325)\end{array}$ & $\begin{array}{l}\text { Machinery } \\
\text { (333) }\end{array}$ & $\begin{array}{l}\text { Food } \\
(311)\end{array}$ & Average \\
\hline
\end{tabular}

\section{TOTAL EMPLOYMENT}

Correlations

$\begin{array}{cccccccccc}\operatorname{corr}\left(\mathrm{Y}_{\mathrm{i}}^{\mathrm{MX}}, \mathrm{Y}_{\mathrm{i}}^{\mathrm{US}}\right) & -0.42 & -0.96 & -0.34 & 0.82 & 0.17 & 0.97 & -0.27 & -0.52 & -0.07 \\ \operatorname{corr}\left(\mathrm{Y}^{\mathrm{MX}}, \mathrm{Y}^{\mathrm{US}}\right) & -0.07 & -0.07 & -0.07 & -0.07 & -0.07 & -0.07 & -0.07 & -0.07 & -0.07 \\ \operatorname{corr}\left(\mathrm{Y}_{\mathrm{i}}^{\mathrm{MX}}, \mathrm{Y}^{\mathrm{MX}}\right) & 0.93 & 0.88 & 0.88 & 0.07 & 0.89 & 0.82 & 0.84 & 0.54 & 0.73 \\ \operatorname{corr}\left(\mathrm{Y}_{\mathrm{i}}^{\mathrm{CA}}, \mathrm{Y}^{\mathrm{CA}}\right) & 0.99 & 0.79 & 0.87 & 0.78 & 0.80 & -0.46 & 0.94 & 0.74 & 0.68\end{array}$

OUTPUT

\section{Correlations}

\begin{tabular}{llllllllll}
$\operatorname{corr}\left(\mathrm{Y}_{\mathrm{i}}^{\mathrm{MX}}, \mathrm{Y}_{\mathrm{i}}^{\mathrm{US}}\right)$ & 0.62 & -0.56 & -0.01 & n.a. & 0.90 & 0.90 & 0.27 & -0.02 & 0.30 \\
$\operatorname{corr}\left(\mathrm{Y}^{\mathrm{MX}}, \mathrm{Y}^{\mathrm{US}}\right)$ & 0.68 & 0.68 & 0.68 & 0.68 & 0.68 & 0.68 & 0.68 & 0.68 & 0.68 \\
$\operatorname{corr}\left(\mathrm{Y}_{\mathrm{i}}^{\mathrm{MX}}, \mathrm{Y}^{\mathrm{MX}}\right)$ & 0.99 & 0.94 & 0.93 & 0.29 & 0.96 & 0.98 & 0.95 & 0.91 & 0.87 \\
$\operatorname{corr}\left(\mathrm{Y}_{\mathrm{i}}^{\mathrm{CA}}, \mathrm{Y}^{\mathrm{CA}}\right)$ & 0.94 & -0.25 & 0.70 & n.a. & 0.80 & 0.34 & 0.92 & 0.00 & 0.50 \\
\hline
\end{tabular}

Notes: The table above shows correlation coefficients. For data details see Table 7. 
Table 13. Correlation Coefficients for Mexico and Arizona Offshoring Industries: Annual Employment and Output

\begin{tabular}{|c|c|c|c|c|c|c|c|c|}
\hline $\begin{array}{c}\text { Electrical } \\
\text { Equipment, } \\
\text { Appliance, and } \\
\text { Component } \\
\text { (335) }\end{array}$ & $\begin{array}{l}\text { Transportation } \\
\text { Equipment } \\
\text { (336) }\end{array}$ & $\begin{array}{c}\text { Apparel } \\
(315)\end{array}$ & $\begin{array}{l}\text { Leather } \\
\text { and } \\
\text { Allied } \\
\text { Product } \\
(316)\end{array}$ & $\begin{array}{l}\text { Furniture } \\
\text { and } \\
\text { Related } \\
\text { Product } \\
\text { (337) }\end{array}$ & $\begin{array}{c}\text { Chemical } \\
(325)\end{array}$ & $\begin{array}{l}\text { Machinery } \\
\text { (333) }\end{array}$ & $\begin{array}{l}\text { Food } \\
(311)\end{array}$ & Average \\
\hline
\end{tabular}

\begin{tabular}{llllllllll}
\hline \multicolumn{1}{l}{ TOTAL EMPLOYMENT } \\
Correlations
\end{tabular}

\section{OUTPUT}

Correlations

\begin{tabular}{cccccccccc}
$\operatorname{corr}\left(\mathrm{Y}_{\mathrm{i}}^{\mathrm{MX}}, \mathrm{Y}_{\mathrm{i}}^{\mathrm{US}}\right)$ & 0.75 & 0.14 & -0.26 & n.a. & 0.99 & 0.02 & -0.35 & 0.01 & 0.19 \\
$\operatorname{corr}\left(\mathrm{Y}^{\mathrm{MX}}, \mathrm{Y}^{\mathrm{US}}\right)$ & 0.30 & 0.30 & 0.30 & 0.30 & 0.30 & 0.30 & 0.30 & 0.30 & 0.30 \\
$\operatorname{corr}\left(\mathrm{Y}_{\mathrm{i}}^{\mathrm{MX}}, \mathrm{Y}^{\mathrm{MX}}\right)$ & 0.99 & 0.94 & 0.93 & 0.29 & 0.96 & 0.98 & 0.95 & 0.91 & 0.87 \\
$\operatorname{corr}\left(\mathrm{Y}_{\mathrm{i}}^{\mathrm{AZ}}, \mathrm{Y}^{\mathrm{AZ}}\right)$ & 0.91 & 0.46 & -0.47 & n.a. & 0.58 & 0.59 & -0.29 & 0.50 & 0.32 \\
\hline
\end{tabular}

Notes: The table above shows correlation coefficients. For data details see Table 8 . 
Table 14. Correlation Coefficients for Mexico and Great Lakes Offshoring Industries: Annual Employment and Output

\begin{tabular}{|c|c|c|c|c|c|c|c|c|}
\hline $\begin{array}{c}\text { Electrical } \\
\text { Equipment, } \\
\text { Appliance, and } \\
\text { Component } \\
\text { (335) }\end{array}$ & $\begin{array}{l}\text { Transportation } \\
\text { Equipment } \\
\text { (336) }\end{array}$ & $\begin{array}{c}\text { Apparel } \\
(315)\end{array}$ & $\begin{array}{l}\text { Leather } \\
\text { and } \\
\text { Allied } \\
\text { Product } \\
(316)\end{array}$ & $\begin{array}{c}\text { Furniture } \\
\text { and } \\
\text { Related } \\
\text { Product } \\
\text { (337) }\end{array}$ & $\begin{array}{c}\text { Chemical } \\
\text { (325) }\end{array}$ & $\begin{array}{l}\text { Machinery } \\
\text { (333) }\end{array}$ & $\begin{array}{l}\text { Food } \\
(311)\end{array}$ & Average \\
\hline
\end{tabular}

\section{TOTAL EMPLOYMENT}

Correlations

$\begin{array}{cccccccccc}\operatorname{corr}\left(\mathrm{Y}_{\mathrm{i}}^{\mathrm{MX}}, \mathrm{Y}_{\mathrm{i}}^{\mathrm{US}}\right) & -0.52 & \text { n.a. } & -0.91 & 0.76 & 0.04 & -0.74 & -0.69 & -0.37 & -0.35 \\ \operatorname{corr}\left(\mathrm{Y}^{\mathrm{MX}}, \mathrm{Y}^{\mathrm{US}}\right) & -0.23 & -0.23 & -0.23 & -0.23 & -0.23 & -0.23 & -0.23 & -0.23 & -0.23 \\ \operatorname{corr}\left(\mathrm{Y}_{\mathrm{i}}^{\mathrm{MX}}, \mathrm{Y}^{\mathrm{MX}}\right) & 0.93 & 0.88 & 0.88 & 0.07 & 0.89 & 0.82 & 0.84 & 0.54 & 0.73 \\ \operatorname{corr}\left(\mathrm{Y}_{\mathrm{i}}^{\mathrm{GL}}, \mathrm{Y}^{\mathrm{GL}}\right) & 1.03 & \text { n.a. } & -0.37 & 0.93 & 0.93 & 0.98 & 1.04 & 0.97 & 0.79\end{array}$

OUTPUT

\section{Correlations}

\begin{tabular}{llllllllll}
$\operatorname{corr}\left(\mathrm{Y}_{\mathrm{i}}^{\mathrm{MX}}, \mathrm{Y}_{\mathrm{i}}^{\mathrm{US}}\right)$ & -0.73 & -0.06 & -0.61 & n.a. & 0.88 & 0.94 & -0.61 & -0.72 & -0.13 \\
$\operatorname{corr}\left(\mathrm{Y}^{\mathrm{MX}}, \mathrm{Y}^{\mathrm{US}}\right)$ & -0.08 & -0.08 & -0.08 & -0.08 & -0.08 & -0.08 & -0.08 & -0.08 & -0.08 \\
$\operatorname{corr}\left(\mathrm{Y}_{\mathrm{i}}^{\mathrm{MX}}, \mathrm{Y}^{\mathrm{MX}}\right)$ & 0.99 & 0.94 & 0.93 & 0.29 & 0.96 & 0.98 & 0.95 & 0.91 & 0.87 \\
$\operatorname{corr}\left(\mathrm{Y}_{\mathrm{i}}^{\mathrm{GL}}, \mathrm{Y}^{\mathrm{GL}}\right)$ & 0.46 & 0.89 & 0.56 & n.a. & 0.50 & 0.12 & 0.68 & 0.32 & 0.51 \\
\hline
\end{tabular}

Notes: The table above shows correlation coefficients. For data details see table 9. 
Table 15. Regression results for variation in Mexico and U.S. Offshoring Industries: Monthly Total Employment

\begin{tabular}{|c|c|c|c|c|c|c|c|c|}
\hline & $\begin{array}{c}\text { Electrical Equipment, } \\
\text { Appliance, and } \\
\text { Component } \\
(335)\end{array}$ & $\begin{array}{l}\text { Transportation } \\
\text { Equipment } \\
(336)\end{array}$ & $\begin{array}{c}\text { Apparel } \\
(315)\end{array}$ & $\begin{array}{l}\text { Leather and } \\
\text { Allied Product } \\
\text { (316) }\end{array}$ & $\begin{array}{l}\text { Furniture and } \\
\text { Related } \\
\text { Product (337) }\end{array}$ & $\begin{array}{c}\text { Chemical } \\
(325)\end{array}$ & $\begin{array}{c}\text { Machinery } \\
\text { (333) }\end{array}$ & $\begin{array}{l}\text { Food } \\
(311)\end{array}$ \\
\hline Mexico & $\begin{array}{c}0.0051 \\
(0.0047)\end{array}$ & $\begin{array}{c}0.0051 \\
(0.0038)\end{array}$ & $\begin{array}{c}0.0051 \\
(0.0208)\end{array}$ & $\begin{array}{c}0.0051 \\
(0.0078)\end{array}$ & $\begin{array}{c}0.0051 \\
(0.0044)\end{array}$ & $\begin{array}{c}0.0051 \\
(0.0125)\end{array}$ & $\begin{array}{c}0.0051 \\
(0.0091)\end{array}$ & $\begin{array}{c}0.0051 * * * \\
(0.0018)\end{array}$ \\
\hline $\begin{array}{l}\text { Offshoring } \\
\text { Industry }\end{array}$ & $\begin{array}{c}0.0094 * * \\
(0.0047)\end{array}$ & $\begin{array}{l}-0.0026 \\
(0.0038)\end{array}$ & $\begin{array}{c}0.2169 * * * \\
(0.0208)\end{array}$ & $\begin{array}{c}0.1806 * * * \\
(0.0078)\end{array}$ & $\begin{array}{l}-0.0029 \\
(0.0044)\end{array}$ & $\begin{array}{l}-0.0032 \\
(0.0125)\end{array}$ & $\begin{array}{c}0.0026 \\
(0.0091)\end{array}$ & $\begin{array}{c}- \\
0.0062 * * * \\
(0.0018)\end{array}$ \\
\hline $\begin{array}{l}\text { Mexico } \\
\text { times } \\
\text { Offshoring }\end{array}$ & $\begin{array}{c}0.0847 * * * \\
(0.0066)\end{array}$ & $\begin{array}{c}0.0898 * * * \\
(0.0054)\end{array}$ & $\begin{array}{c}0.1725 * * * \\
(0.0294)\end{array}$ & $\begin{array}{c}-0.1587 * * * \\
(0.0110)\end{array}$ & $\begin{array}{c}0.0798 * * * \\
(0.0062)\end{array}$ & $\begin{array}{c}0.2227 * * * \\
(0.0177)\end{array}$ & $\begin{array}{c}0.2573 * * * \\
(0.0128)\end{array}$ & $\begin{array}{r}0.0198 * * * \\
(0.0025)\end{array}$ \\
\hline R-squared & 0.57 & 0.62 & 0.55 & 0.60 & 0.50 & 0.46 & 0.69 & 0.39 \\
\hline $\begin{array}{c}\text { Adjusted } \\
\text { R-Squared }\end{array}$ & 0.56 & 0.62 & 0.54 & 0.59 & 0.50 & 0.45 & 0.69 & 0.39 \\
\hline $\begin{array}{l}\text { Number of } \\
\text { Observations }\end{array}$ & 816 & 816 & 816 & 816 & 816 & 816 & 816 & 816 \\
\hline Notes: & $\begin{array}{l}\text { Each column reports ordi } \\
\text { employment for the perio } \\
\text { dummy, and interaction } t \\
\text { in parenthesis. Standard } \\
\text { indicates significant at } 50\end{array}$ & $\begin{array}{l}\text { least squares } 1 \\
\text { nuary } 1990 \text { thr } \\
\text { between count } \\
\text { s are obtained } \\
\text { el; and } * \text { indic }\end{array}$ & $\begin{array}{l}\text { ults for a re } \\
\text { gh } 2006 . R \\
\text { and offsho } \\
\text { rough boot } \\
\text { es significa }\end{array}$ & $\begin{array}{l}\text { ssion of the mo } \\
\text { ressors include } \\
\text { dummies. Sea } \\
\text { pping, using } 10 \\
\text { the } 10 \% \text { level }\end{array}$ & $\begin{array}{l}\text { ly squared dev } \\
\text { nstant term, co } \\
\text { ally adjusted di } \\
\text { O repetitions. }\end{array}$ & $\begin{array}{l}\text { on from the } \\
\text { ry dummy } \\
\text { were empl } \\
\text { indicates s }\end{array}$ & $\begin{array}{l}\text { nean of } \log t \\
\text { ffshoring in } \\
\text { ed. Standar } \\
\text { nificant at } 1\end{array}$ & $\begin{array}{l}\text { tal } \\
\text { ustry } \\
\text { errors are } \\
\text { level; ** }\end{array}$ \\
\hline
\end{tabular}


Table 16. Regression results for variation in Mexico and U.S. Offshoring Industries: Monthly Production Worker Employment

\begin{tabular}{|c|c|c|c|c|c|c|c|c|}
\hline & $\begin{array}{c}\text { Electrical Equipment, } \\
\text { Appliance, and } \\
\text { Component } \\
(335) \\
\end{array}$ & $\begin{array}{c}\text { Transportation } \\
\text { Equipment } \\
\text { (336) }\end{array}$ & $\begin{array}{l}\text { Apparel } \\
(315)\end{array}$ & $\begin{array}{l}\text { Leather and } \\
\text { Allied Product } \\
\text { (316) }\end{array}$ & $\begin{array}{c}\text { Furniture and } \\
\text { Related Product } \\
\text { (337) }\end{array}$ & $\begin{array}{l}\text { Chemical } \\
\text { (325) }\end{array}$ & $\begin{array}{l}\text { Machinery } \\
\text { (333) }\end{array}$ & Food (311) \\
\hline Constant & $\begin{array}{l}0.0065^{*} \\
(0.0035)\end{array}$ & $\begin{array}{c}0.0065^{* * *} \\
(0.0027)\end{array}$ & $\begin{array}{c}0.0081 \\
(0.0154)\end{array}$ & $\begin{array}{c}0.0081 \\
(0.0064)\end{array}$ & $\begin{array}{c}0.0081 * * * \\
(0.0031)\end{array}$ & $\begin{array}{c}0.0081 \\
(0.0081)\end{array}$ & $\begin{array}{c}0.0081 \\
(0.0066)\end{array}$ & $\begin{array}{c}0.0081 * * * \\
(0.0014)\end{array}$ \\
\hline Mexico & $\begin{array}{c}0.0051 \\
(0.0049)\end{array}$ & $\begin{array}{c}0.0051 \\
(0.0038)\end{array}$ & $\begin{array}{c}0.0054 \\
(0.0218)\end{array}$ & $\begin{array}{c}0.0054 \\
(0.0091)\end{array}$ & $\begin{array}{c}0.0054 \\
(0.0043)\end{array}$ & $\begin{array}{c}0.0054 \\
(0.0114)\end{array}$ & $\begin{array}{c}0.0054 \\
(0.0093)\end{array}$ & $\begin{array}{c}0.0054^{* * *} \\
(0.0020)\end{array}$ \\
\hline $\begin{array}{l}\text { Offshoring } \\
\text { Industry }\end{array}$ & $\begin{array}{c}0.0158^{* * *} \\
(0.0049)\end{array}$ & $\begin{array}{l}-0.0019 \\
(0.0038)\end{array}$ & $\begin{array}{c}0.2659 * * * \\
(0.0218)\end{array}$ & $\begin{array}{c}0.2135^{* * *} \\
(0.0091)\end{array}$ & $\begin{array}{l}-0.0032 \\
(0.0043)\end{array}$ & $\begin{array}{l}-0.0039 \\
(0.0114)\end{array}$ & $\begin{array}{c}0.0047 \\
(0.0093)\end{array}$ & $\begin{array}{c}-0.0077 * * * \\
(0.0020)\end{array}$ \\
\hline $\begin{array}{c}\text { Mexico } \\
\text { times }\end{array}$ & $0.0747 * * *$ & $0.0838 * * *$ & $0.1147 * * *$ & $-0.1918 * * *$ & $0.0714 * * *$ & $0.189 * * *$ & $0.2503 * * *$ & $0.0219 * * *$ \\
\hline Offshoring & $(0.0069)$ & $(0.0053)$ & $(0.0309)$ & $(0.0129)$ & $(0.0061)$ & $(0.0161)$ & $(0.0131)$ & $(0.0028)$ \\
\hline R-squared & 0.53 & 0.61 & 0.54 & 0.60 & 0.48 & 0.43 & 0.67 & 0.39 \\
\hline $\begin{array}{l}\text { Adjusted } \\
\text { R-Squared }\end{array}$ & 0.53 & 0.61 & 0.54 & 0.60 & 0.48 & 0.43 & 0.67 & 0.39 \\
\hline $\begin{array}{l}\text { Number of } \\
\text { Observations }\end{array}$ & 816 & 816 & 816 & 816 & 816 & 816 & 816 & 816 \\
\hline Notes: & $\begin{array}{l}\text { Each column reports ordir } \\
\text { workers employment for } t \\
\text { dummy, and interaction te } \\
\text { parenthesis. Standard erro } \\
\text { indicates significant at 5\% }\end{array}$ & $\begin{array}{l}\text { least squares } \\
\text { eriod January } \\
\text { etween coun }\end{array}$ & $\begin{array}{l}\text { lits for a r } \\
90 \text { througl }\end{array}$ & $\begin{array}{l}\text { ession of the mo } \\
06 \text {. Regressors }\end{array}$ & $\begin{array}{l}\text { ly squared devi } \\
\text { lude a constant } \\
\text { ally adjusted da }\end{array}$ & $\begin{array}{l}n \text { from th } \\
m \text {, country }\end{array}$ & $\begin{array}{l}\text { hean of log } \\
\text { ummy, off } \\
\text { ed. Standa }\end{array}$ & $\begin{array}{l}\text { duction } \\
\text { ing industry } \\
\text { rrors are in } \\
\text { el; } * *\end{array}$ \\
\hline
\end{tabular}


Table 17. Regression results for variation in Mexico and U.S. Offshoring Industries: Monthly Output

\begin{tabular}{|c|c|c|c|c|c|c|c|c|}
\hline & $\begin{array}{c}\text { Electrical Equipment, } \\
\text { Appliance, and } \\
\text { Component } \\
(335) \\
\end{array}$ & $\begin{array}{l}\text { Transportation } \\
\text { Equipment } \\
(336)\end{array}$ & $\begin{array}{c}\text { Apparel } \\
(315)\end{array}$ & $\begin{array}{l}\text { Leather and } \\
\text { Allied } \\
\text { Product } \\
(316) \\
\end{array}$ & $\begin{array}{l}\text { Furniture and } \\
\text { Related } \\
\text { Product (337) }\end{array}$ & $\begin{array}{c}\text { Chemical } \\
\text { (325) }\end{array}$ & $\begin{array}{c}\text { Machinery } \\
\text { (333) }\end{array}$ & $\begin{array}{l}\text { Food } \\
(311)\end{array}$ \\
\hline Constant & $\begin{array}{c}0.0359 * * * \\
(0.0053)\end{array}$ & $\begin{array}{c}0.0359 * * * \\
(0.0043)\end{array}$ & $\begin{array}{c}0.03591 * \\
(0.0186)\end{array}$ & $\begin{array}{c}0.0359 * * * \\
(0.0030)\end{array}$ & $\begin{array}{c}0.0359 * * * \\
(0.0078)\end{array}$ & $\begin{array}{c}0.0359 * * * \\
(0.0122)\end{array}$ & $\begin{array}{c}0.0359 * * * \\
(0.0107)\end{array}$ & $\begin{array}{c}0.0359 * * * \\
(0.0053)\end{array}$ \\
\hline Mexico & $\begin{array}{c}-0.0228 * * * \\
(0.0075)\end{array}$ & $\begin{array}{c}-0.0228 * * * \\
(0.0060)\end{array}$ & $\begin{array}{l}-0.0228 \\
(0.0262)\end{array}$ & $\begin{array}{c}-0.0228 * * * \\
(0.0042)\end{array}$ & $\begin{array}{c}-0.0228 * * \\
(0.0110)\end{array}$ & $\begin{array}{l}-0.0228 \\
(0.0172)\end{array}$ & $\begin{array}{l}-0.0228 \\
(0.0152)\end{array}$ & $\begin{array}{c}- \\
0.0228 * * * \\
(0.0075)\end{array}$ \\
\hline $\begin{array}{l}\text { Offshoring } \\
\text { Industry }\end{array}$ & $\begin{array}{c}-0.0254 * * * \\
(0.0075)\end{array}$ & $\begin{array}{c}-0.0184 * * * \\
(0.0060)\end{array}$ & $\begin{array}{c}0.0657 * * * \\
(0.0262)\end{array}$ & $\begin{array}{c}0.0592 * * * \\
(0.0042)\end{array}$ & $\begin{array}{l}-0.0171 \\
(0.0110)\end{array}$ & $\begin{array}{l}-0.0230 \\
(0.0172)\end{array}$ & $\begin{array}{l}-0.0215 \\
(0.0152)\end{array}$ & $\begin{array}{c}- \\
0.0298 * * * \\
(0.0075)\end{array}$ \\
\hline $\begin{array}{l}\text { Mexico } \\
\text { times } \\
\text { Offshoring }\end{array}$ & $0.2292 * * *$ & $0.1513 * * *$ & $0.5221 * * *$ & $-0.0576 * * *$ & $0.3044 * * *$ & $0.3499 * * *$ & $0.4077 * * *$ & $\begin{array}{r}0.1148 * * * \\
(0.0106)\end{array}$ \\
\hline R-squared & 0.68 & 0.61 & 0.57 & 0.60 & 0.65 & 0.49 & 0.63 & 0.33 \\
\hline $\begin{array}{c}\text { Adjusted } \\
\text { R-Squared }\end{array}$ & 0.68 & 0.61 & 0.57 & 0.60 & 0.65 & 0.49 & 0.63 & 0.33 \\
\hline $\begin{array}{l}\text { Number of } \\
\text { Observations }\end{array}$ & 816 & 816 & 816 & 816 & 816 & 816 & 816 & 816 \\
\hline Notes: & \multicolumn{8}{|c|}{$\begin{array}{l}\text { Each column reports ordinary least squares results for a regression of the monthly squared deviation from the mean of log output for } \\
\text { the period January } 1990 \text { through } 2006 \text {. Regressors include a constant term, country dummy, offshoring industry dummy, and } \\
\text { interaction term between country and offshoring dummies. Inflation- and seasonally-adjusted adjusted data were employed. } \\
\text { Standard errors are in parenthesis. Standard errors are obtained through bootstrapping, using } 10,000 \text { repetitions. } * * * \text { indicates } \\
\text { significant at } 1 \% \text { level; ** indicates significant at } 5 \% \text { level; and * indicates significant at the } 10 \% \text { level. }\end{array}$} \\
\hline
\end{tabular}


Table 18. Regression results for variation in Mexico and Texas Offshoring Industries: Annual Employment

\begin{tabular}{|c|c|c|c|c|c|c|c|c|}
\hline & $\begin{array}{l}\text { Electrical Equipment, } \\
\text { Appliance, and } \\
\text { Component } \\
(335)\end{array}$ & $\begin{array}{c}\text { Transportation } \\
\text { Equipment } \\
\text { (336) }\end{array}$ & $\begin{array}{c}\text { Apparel } \\
(315)\end{array}$ & $\begin{array}{l}\text { Leather and } \\
\text { Allied } \\
\text { Product } \\
(316)\end{array}$ & $\begin{array}{l}\text { Furniture } \\
\text { and Related } \\
\text { Product } \\
(337)\end{array}$ & $\begin{array}{c}\text { Chemical } \\
(325)\end{array}$ & $\begin{array}{l}\text { Machinery } \\
\text { (333) }\end{array}$ & $\begin{array}{l}\text { Food } \\
(311)\end{array}$ \\
\hline Constant & $\begin{array}{c}0.0033 \\
(0.0114)\end{array}$ & $\begin{array}{c}0.0033 \\
(0.0090)\end{array}$ & $\begin{array}{c}0.0033 \\
(0.0668)\end{array}$ & $\begin{array}{c}0.0033 \\
(0.0056)\end{array}$ & $\begin{array}{c}0.0033 \\
(0.0111)\end{array}$ & $\begin{array}{c}0.0033 \\
(0.0307)\end{array}$ & $\begin{array}{c}0.0033 \\
(0.0221)\end{array}$ & $\begin{array}{c}0.0033 \\
(0.0033)\end{array}$ \\
\hline Mexico & $\begin{array}{c}0.0080 \\
(0.0161)\end{array}$ & $\begin{array}{c}0.0080 \\
(0.0127)\end{array}$ & $\begin{array}{c}0.0080 \\
(0.0945)\end{array}$ & $\begin{array}{c}0.0080 \\
(0.0079)\end{array}$ & $\begin{array}{c}0.0800 \\
(0.0157)\end{array}$ & $\begin{array}{c}0.0080 \\
(0.0434)\end{array}$ & $\begin{array}{c}0.0080 \\
(0.0312)\end{array}$ & $\begin{array}{c}0.008^{*} \\
(0.0046)\end{array}$ \\
\hline $\begin{array}{l}\text { Offshoring } \\
\text { Industry }\end{array}$ & $\begin{array}{c}0.0127 \\
(0.0161)\end{array}$ & $\begin{array}{c}-0.0003 \\
(0.0127)\end{array}$ & $\begin{array}{c}0.3566^{* * *} \\
(0.0945)\end{array}$ & $\begin{array}{c}0.0246^{* * *} \\
(0.0079)\end{array}$ & $\begin{array}{c}0.0231 \\
(0.0157)\end{array}$ & $\begin{array}{c}0.0004 \\
(0.0434)\end{array}$ & $\begin{array}{c}0.0008 \\
(0.0312)\end{array}$ & $\begin{array}{l}-0.0026 \\
(0.0046)\end{array}$ \\
\hline $\begin{array}{l}\text { Mexico } \\
\text { times } \\
\text { Offshoring }\end{array}$ & $\begin{array}{c}0.0805^{* * *} \\
(0.0228)\end{array}$ & $\begin{array}{c}0.0866^{* * *} \\
(0.0179)\end{array}$ & $\begin{array}{l}0.0302 \\
(0.1336)\end{array}$ & $\begin{array}{c}-0.004 \\
(0.0112)\end{array}$ & $\begin{array}{c}0.0529 * * * \\
(0.0223)\end{array}$ & $\begin{array}{c}0.2164 * * * \\
(0.0614)\end{array}$ & $\begin{array}{c}0.2573 * * * \\
(0.0441)\end{array}$ & $\begin{array}{l}0.0112 * \\
(0.0065)\end{array}$ \\
\hline R-squared & 0.58 & 0.65 & 0.50 & 0.49 & 0.51 & 0.46 & 0.70 & 0.44 \\
\hline $\begin{array}{l}\text { Adjusted } \\
\text { R-Squared }\end{array}$ & 0.56 & 0.63 & 0.48 & 0.46 & 0.49 & 0.44 & 0.68 & 0.41 \\
\hline $\begin{array}{l}\text { Number of } \\
\text { Observations }\end{array}$ & 816 & 816 & 816 & 816 & 816 & 816 & 816 & 816 \\
\hline Notes: & $\begin{array}{l}\text { Each column reports ordin } \\
\text { employment for the perioc } \\
\text { dummy, and interaction te } \\
\text { are obtained through boot } \\
5 \% \text { level; and * indicates }\end{array}$ & $\begin{array}{l}\text { least squares } r \\
90 \text { through } 200 \\
\text { between countr } \\
\text { pping, using } 10 \\
\text { ificant at the } 10\end{array}$ & $\begin{array}{l}\text { sults for a r } \\
5 \text {. Regresso } \\
\text { and offsho } \\
000 \text { repetitic } \\
\% \text { level. }\end{array}$ & $\begin{array}{l}\text { ression of th } \\
\text { include a co } \\
\text { ng dummies } \\
\text { s. } * * * \text { indic }\end{array}$ & $\begin{array}{l}\text { nual square } \\
\text { ant term, cou } \\
\text { andard error } \\
\text { significant }\end{array}$ & $\begin{array}{l}\text { leviation fr } \\
\text { ry dummy, } \\
\text { are in paren } \\
1 \% \text { level; * }\end{array}$ & $\begin{array}{l}\text { the mean of } \\
\text { fsshoring ind } \\
\text { esis. Standar } \\
\text { indicates sigr }\end{array}$ & $\begin{array}{l}\log \\
\text { stry } \\
\text { i errors } \\
\text { ificant at }\end{array}$ \\
\hline
\end{tabular}


Table 19. Regression results for variation in Mexico and Texas Offshoring Industries: Annual Output

\begin{tabular}{|c|c|c|c|c|c|c|c|c|}
\hline & $\begin{array}{c}\text { Electrical Equipment, } \\
\text { Appliance, and } \\
\text { Component } \\
(335)\end{array}$ & $\begin{array}{l}\text { Transportation } \\
\text { Equipment } \\
\text { (336) }\end{array}$ & $\begin{array}{c}\text { Apparel } \\
(315)\end{array}$ & $\begin{array}{l}\text { Leather and } \\
\text { Allied } \\
\text { Product } \\
(316)\end{array}$ & $\begin{array}{l}\text { Furniture } \\
\text { and Related } \\
\text { Product } \\
(337)\end{array}$ & $\begin{array}{c}\text { Chemical } \\
\text { (325) }\end{array}$ & $\begin{array}{c}\text { Machinery } \\
\text { (333) }\end{array}$ & $\begin{array}{l}\text { Food } \\
(311)\end{array}$ \\
\hline Constant & $\begin{array}{c}0.0168 \\
(0.0194)\end{array}$ & $\begin{array}{c}0.0168 \\
(0.0144)\end{array}$ & $\begin{array}{c}0.0168 \\
(0.0678)\end{array}$ & n.a. & $\begin{array}{c}0.0168 \\
(0.0271)\end{array}$ & $\begin{array}{c}0.0168 \\
(0.0435)\end{array}$ & $\begin{array}{c}0.0168 \\
(0.0375)\end{array}$ & $\begin{array}{c}0.0168 \\
(0.0135)\end{array}$ \\
\hline Mexico & $\begin{array}{l}-0.0045 \\
(0.0274)\end{array}$ & $\begin{array}{c}-0.0045 \\
(0.0204)\end{array}$ & $\begin{array}{c}-0.0045 \\
(0.0959)\end{array}$ & n.a. & $\begin{array}{c}-0.0045 \\
(0.0383)\end{array}$ & $\begin{array}{c}-0.0045 \\
(0.0616)\end{array}$ & $\begin{array}{c}-0.0045 \\
(0.0530)\end{array}$ & $\begin{array}{c}-0.0045 \\
(0.0190)\end{array}$ \\
\hline $\begin{array}{l}\text { Offshoring } \\
\text { Industry }\end{array}$ & $\begin{array}{c}0.0189 \\
(0.0274)\end{array}$ & $\begin{array}{c}0.0024 \\
(0.0204)\end{array}$ & $\begin{array}{c}0.1270 \\
(0.0959)\end{array}$ & n.a. & $\begin{array}{c}0.0132 \\
(0.0383)\end{array}$ & $\begin{array}{c}0.0619 \\
(0.0616)\end{array}$ & $\begin{array}{c}0.0411 \\
(0.0530)\end{array}$ & $\begin{array}{c}-0.0109 \\
(0.0190)\end{array}$ \\
\hline $\begin{array}{l}\text { Mexico } \\
\text { times } \\
\text { Offshoring }\end{array}$ & $\begin{array}{c}0.1831 * * * \\
(0.0388)\end{array}$ & $\begin{array}{c}0.1287 * * * \\
(0.0289)\end{array}$ & $\begin{array}{c}0.4562 * * * \\
(0.1357)\end{array}$ & n.a. & $\begin{array}{c}0.2715^{* * *} \\
(0.0542)\end{array}$ & $\begin{array}{c}0.2601 * * * \\
(0.0871)\end{array}$ & $\begin{array}{l}0.341 * * * \\
(0.0749)\end{array}$ & $\begin{array}{c}0.0747 * * * \\
(0.0269)\end{array}$ \\
\hline R-squared & 0.66 & 0.61 & 0.56 & n.a. & 0.65 & 0.49 & 0.64 & 0.35 \\
\hline $\begin{array}{l}\text { Adjusted } \\
\text { R-Squared }\end{array}$ & 0.65 & 0.60 & 0.54 & n.a. & 0.64 & 0.47 & 0.62 & 0.32 \\
\hline $\begin{array}{l}\text { Number of } \\
\text { Observations }\end{array}$ & 816 & 816 & 816 & n.a. & 816 & 816 & 816 & 816 \\
\hline Notes: & $\begin{array}{l}\text { Each column reports ordi } \\
\text { for the period } 1990 \text { throu } \\
\text { interaction term between } \\
\text { through bootstrapping, us } \\
* \text { indicates significant at }\end{array}$ & $\begin{array}{l}\text { least squares } r \\
006 \text {. Regresso } \\
\text { try and offsho } \\
10,000 \text { repetitic } \\
0 \% \text { level. }\end{array}$ & $\begin{array}{l}\text { alts for a re } \\
\text { nclude a ce } \\
\text { g dummies } \\
* * * \text { indic }\end{array}$ & $\begin{array}{l}\text { ession of the } \\
\text { stant term, c } \\
\text { Standard err } \\
\text { es significar }\end{array}$ & $\begin{array}{l}\text { nual square } \\
\text { try dummy } \\
\text { are in parer } \\
1 \% \text { level; }\end{array}$ & $\begin{array}{l}\text { eviation fr } \\
\text { fshoring in } \\
\text { sis. Stand } \\
\text { indicates si }\end{array}$ & $\begin{array}{l}\text { n the mean o } \\
\text { ustry dummy } \\
\text { d errors are } \\
\text { nificant at } 5^{\circ}\end{array}$ & $\begin{array}{l}\text { log output } \\
\text { and } \\
\text { btained } \\
\text { level; and }\end{array}$ \\
\hline
\end{tabular}


Table 20. Regression results for variation in Mexico and California Offshoring Industries: Annual Employment

\begin{tabular}{|c|c|c|c|c|c|c|c|c|}
\hline & $\begin{array}{l}\text { Electrical Equipment, } \\
\text { Appliance, and } \\
\text { Component } \\
(335)\end{array}$ & $\begin{array}{c}\text { Transportation } \\
\text { Equipment } \\
\text { (336) }\end{array}$ & $\begin{array}{c}\text { Apparel } \\
(315)\end{array}$ & $\begin{array}{l}\text { Leather and } \\
\text { Allied } \\
\text { Product } \\
(316)\end{array}$ & $\begin{array}{l}\text { Furniture } \\
\text { and Related } \\
\text { Product } \\
\text { (337) }\end{array}$ & $\begin{array}{c}\text { Chemical } \\
(325)\end{array}$ & $\begin{array}{l}\text { Machinery } \\
\quad(333)\end{array}$ & $\begin{array}{l}\text { Food } \\
(311)\end{array}$ \\
\hline Constant & $\begin{array}{c}0.0062 \\
(0.0115)\end{array}$ & $\begin{array}{c}0.0062 \\
(0.0109)\end{array}$ & $\begin{array}{c}0.0062 \\
(0.0463)\end{array}$ & $\begin{array}{c}0.0062 \\
(0.0078)\end{array}$ & $\begin{array}{c}0.0062 \\
(0.0107)\end{array}$ & $\begin{array}{c}0.0062 \\
(0.0308)\end{array}$ & $\begin{array}{c}0.0062 \\
(0.0221)\end{array}$ & $\begin{array}{l}0.0062 * \\
(0.0035)\end{array}$ \\
\hline Mexico & $\begin{array}{c}0.0051 \\
(0.0163)\end{array}$ & $\begin{array}{c}0.0051 \\
(0.0154)\end{array}$ & $\begin{array}{c}0.0051 \\
(0.0655)\end{array}$ & $\begin{array}{c}0.0051 \\
(0.0110)\end{array}$ & $\begin{array}{c}0.0051 \\
(0.0151)\end{array}$ & $\begin{array}{c}0.0051 \\
(0.0435)\end{array}$ & $\begin{array}{c}0.0051 \\
(0.0313)\end{array}$ & $\begin{array}{c}0.0051 \\
(0.0047)\end{array}$ \\
\hline $\begin{array}{l}\text { Offshoring } \\
\text { Industry }\end{array}$ & $\begin{array}{c}0.0075 \\
(0.0163)\end{array}$ & $\begin{array}{c}0.0318^{* *} \\
(0.0154)\end{array}$ & $\begin{array}{c}0.0219 \\
(0.0655)\end{array}$ & $\begin{array}{c}0.0347 * * * \\
(0.0110)\end{array}$ & $\begin{array}{c}0.0014 \\
(0.0151)\end{array}$ & $\begin{array}{l}-0.0035 \\
(0.0435)\end{array}$ & $\begin{array}{c}0.0029 \\
(0.0313)\end{array}$ & $\begin{array}{l}-0.0046 \\
(0.0047)\end{array}$ \\
\hline $\begin{array}{l}\text { Mexico } \\
\text { times } \\
\text { Offshoring }\end{array}$ & $\begin{array}{c}0.0857 * * * \\
(0.0230)\end{array}$ & $\begin{array}{c}0.0545 * * * \\
(0.0218)\end{array}$ & $\begin{array}{c}0.3650 \\
(0.0926)\end{array}$ & $\begin{array}{l}-0.0141 \\
(0.0156)\end{array}$ & $\begin{array}{c}0.0745 * * * \\
(0.0213)\end{array}$ & $0.2204 * * *$ & $\begin{array}{c}0.2552 * * * \\
(0.0442)\end{array}$ & $(0.0067)$ \\
\hline R-squared & 0.57 & 0.59 & 0.54 & 0.42 & 0.52 & 0.46 & 0.70 & 0.44 \\
\hline $\begin{array}{l}\text { Adjusted } \\
\text { R-Squared }\end{array}$ & 0.55 & 0.57 & 0.51 & 0.40 & 0.49 & 0.44 & 0.68 & 0.41 \\
\hline $\begin{array}{l}\text { Number of } \\
\text { Observations }\end{array}$ & 816 & 816 & 816 & 816 & 816 & 816 & 816 & 816 \\
\hline Notes: & $\begin{array}{l}\text { Each column reports ordi } \\
\text { employment for the perio } \\
\text { dummy, and interaction } t \\
\text { are obtained through boo } \\
5 \% \text { level; and * indicates }\end{array}$ & $\begin{array}{l}\text { least squares } r \\
90 \text { through } 200 \\
\text { between countr } \\
\text { pping, using } 10 \\
\text { ificicant at the } 11\end{array}$ & $\begin{array}{l}\text { and offsh } \\
00 \text { repeti } \\
\text { level. }\end{array}$ & $\begin{array}{l}\text { ression of the } \\
\text { include a cor } \\
\text { ng dummies. } \\
\text { s. *** indica }\end{array}$ & $\begin{array}{l}\text { annual square } \\
\text { tant term, col } \\
\text { Standard error } \\
\text { es significant }\end{array}$ & $\begin{array}{l}\text { deviation fr } \\
\text { try dummy, } \\
\text { are in paren } \\
1 \% \text { level; * }\end{array}$ & $\begin{array}{l}\text { m the mean } \\
\text { offshoring in } \\
\text { hesis. Stand } \\
\text { * indicates si }\end{array}$ & $\begin{array}{l}\mathrm{f} \log \\
\text { ustry } \\
\text { rd errors } \\
\text { nificant at }\end{array}$ \\
\hline
\end{tabular}


Table 21. Regression results for variation in Mexico and California Offshoring Industries: Annual Output

\begin{tabular}{|c|c|c|c|c|c|c|c|c|}
\hline & $\begin{array}{c}\text { Electrical Equipment, } \\
\text { Appliance, and } \\
\text { Component } \\
(335)\end{array}$ & $\begin{array}{c}\text { Transportation } \\
\text { Equipment } \\
\text { (336) }\end{array}$ & $\begin{array}{c}\text { Apparel } \\
(315)\end{array}$ & $\begin{array}{l}\text { Leather and } \\
\text { Allied } \\
\text { Product } \\
(316)\end{array}$ & $\begin{array}{l}\text { Furniture } \\
\text { and Related } \\
\text { Product } \\
(337)\end{array}$ & $\begin{array}{c}\text { Chemical } \\
(325)\end{array}$ & $\begin{array}{c}\text { Machinery } \\
\text { (333) }\end{array}$ & $\begin{array}{l}\text { Food } \\
(311)\end{array}$ \\
\hline Constant & $\begin{array}{c}0.0096 \\
(0.0207)\end{array}$ & $\begin{array}{c}0.0096 \\
(0.0153)\end{array}$ & $\begin{array}{c}0.0096 \\
(0.0641)\end{array}$ & n.a. & $\begin{array}{c}0.0096 \\
(0.0269)\end{array}$ & $\begin{array}{c}0.0096 \\
(0.0426)\end{array}$ & $\begin{array}{c}0.0096 \\
(0.0369)\end{array}$ & $\begin{array}{c}0.0096 \\
(0.0133)\end{array}$ \\
\hline Mexico & $\begin{array}{c}0.0027 \\
(0.0293)\end{array}$ & $\begin{array}{c}0.0027 \\
(0.0216)\end{array}$ & $\begin{array}{c}0.0027 \\
(0.0906)\end{array}$ & n.a. & $\begin{array}{c}0.0027 \\
(0.0380)\end{array}$ & $\begin{array}{c}0.0027 \\
(0.0602)\end{array}$ & $\begin{array}{c}0.0027 \\
(0.0522)\end{array}$ & $\begin{array}{c}0.0027 \\
(0.0188)\end{array}$ \\
\hline $\begin{array}{l}\text { Offshoring } \\
\text { Industry }\end{array}$ & $\begin{array}{c}0.0338 \\
(0.0293)\end{array}$ & $\begin{array}{c}0.0198 \\
(0.0216)\end{array}$ & $\begin{array}{l}-0.0025 \\
(0.0906)\end{array}$ & n.a. & $\begin{array}{c}0.0070 \\
(0.0380)\end{array}$ & $\begin{array}{c}0.0861 \\
(0.0602)\end{array}$ & $\begin{array}{c}0.0209 \\
(0.0522)\end{array}$ & $\begin{array}{l}-0.0053 \\
(0.0188)\end{array}$ \\
\hline $\begin{array}{l}\text { Mexico } \\
\text { times } \\
\text { Offshoring }\end{array}$ & $\begin{array}{c}0.1683 * * * \\
(0.0415)\end{array}$ & $\begin{array}{c}0.1113 * * * \\
(0.0305)\end{array}$ & $\begin{array}{c}0.5857 * * * \\
(0.1282)\end{array}$ & n.a. & $\begin{array}{c}0.2776 * * * \\
(0.0537)\end{array}$ & $\begin{array}{c}0.2359 * * * \\
(0.0851)\end{array}$ & $\begin{array}{c}0.3613 * * * \\
(0.0739)\end{array}$ & $\begin{array}{r}0.0691 * * * \\
(0.0266)\end{array}$ \\
\hline R-squared & 0.63 & 0.59 & 0.57 & n.a. & 0.66 & 0.51 & 0.64 & 0.35 \\
\hline $\begin{array}{l}\text { Adjusted } \\
\text { R-Squared }\end{array}$ & 0.62 & 0.57 & 0.55 & n.a. & 0.64 & 0.49 & 0.62 & 0.32 \\
\hline $\begin{array}{l}\text { Number of } \\
\text { Observations }\end{array}$ & 816 & 816 & 816 & n.a. & 816 & 816 & 816 & 816 \\
\hline Notes: & $\begin{array}{l}\text { Each column reports ordi } \\
\text { for the period } 1990 \text { throu } \\
\text { interaction term between } \\
\text { through bootstrapping, us } \\
\text { * indicates significant at }\end{array}$ & $\begin{array}{l}\text { least squares } 1 \\
006 \text {. Regresso } \\
\text { try and offsho } \\
10,000 \text { repetiti } \\
0 \% \text { level. }\end{array}$ & $\begin{array}{l}\text { ults for a re } \\
\text { include a c } \\
\mathrm{g} \text { dummies } \\
* * * \text { indi }\end{array}$ & $\begin{array}{l}\text { ession of the } \\
\text { stant term, c } \\
\text { Standard err } \\
\text { es significal }\end{array}$ & $\begin{array}{l}\text { nual squarec } \\
\text { try dummy, } \\
\text { are in paren } \\
\text { t } 1 \% \text { level; * }\end{array}$ & $\begin{array}{l}\text { leviation fr } \\
\text { ffshoring ir } \\
\text { esis. Stand } \\
\text { indicates s }\end{array}$ & $\begin{array}{l}\mathrm{n} \text { the mean o } \\
\text { ustry dummy } \\
\text { d errors are } \\
\text { nificant at } 5^{\circ}\end{array}$ & $\begin{array}{l}\text { log output } \\
\text { and } \\
\text { btained } \\
6 \text { level; and }\end{array}$ \\
\hline
\end{tabular}


Table 22. Regression results for variation in Mexico and Arizona Offshoring Industries: Annual Employment

\begin{tabular}{|c|c|c|c|c|c|c|c|c|}
\hline & $\begin{array}{c}\text { Electrical Equipment, } \\
\text { Appliance, and } \\
\text { Component } \\
(335)\end{array}$ & $\begin{array}{c}\text { Transportation } \\
\text { Equipment } \\
\text { (336) }\end{array}$ & $\begin{array}{c}\text { Apparel } \\
(315)\end{array}$ & $\begin{array}{l}\text { Leather and } \\
\text { Allied } \\
\text { Product } \\
(316)\end{array}$ & $\begin{array}{l}\text { Furniture } \\
\text { and Related } \\
\text { Product } \\
(337)\end{array}$ & $\begin{array}{c}\text { Chemical } \\
(325)\end{array}$ & $\begin{array}{l}\text { Machinery } \\
\text { (333) }\end{array}$ & $\begin{array}{l}\text { Food } \\
(311)\end{array}$ \\
\hline Constant & $\begin{array}{c}0.0056 \\
(0.0114)\end{array}$ & n.a. & $\begin{array}{c}0.0056 \\
(0.0493)\end{array}$ & $\begin{array}{c}0.0056 \\
(0.0066)\end{array}$ & $\begin{array}{c}0.0056 \\
(0.0116)\end{array}$ & $\begin{array}{c}0.0056 \\
(0.0309)\end{array}$ & $\begin{array}{c}0.0056 \\
(0.0221)\end{array}$ & $\begin{array}{l}0.0056^{*} \\
(0.0034)\end{array}$ \\
\hline Mexico & $\begin{array}{c}0.0057 \\
(0.0161)\end{array}$ & n.a. & $\begin{array}{c}0.0057 \\
(0.0698)\end{array}$ & $\begin{array}{c}0.0057 \\
(0.0093)\end{array}$ & $\begin{array}{c}0.0057 \\
(0.0164)\end{array}$ & $\begin{array}{c}0.0057 \\
(0.0437)\end{array}$ & $\begin{array}{c}0.0057 \\
(0.0313)\end{array}$ & $\begin{array}{c}0.0057 \\
(0.0048)\end{array}$ \\
\hline $\begin{array}{l}\text { Offshoring } \\
\text { Industry }\end{array}$ & $\begin{array}{c}0.0046 \\
(0.0161)\end{array}$ & n.a. & $\begin{array}{c}0.176^{* * *} \\
(0.0698)\end{array}$ & $\begin{array}{c}0.0299 * * * \\
(0.0093)\end{array}$ & $\begin{array}{c}0.0220 \\
(0.0164)\end{array}$ & $\begin{array}{c}0.0202 \\
(0.0437)\end{array}$ & $\begin{array}{c}0.0086 \\
(0.0313)\end{array}$ & $\begin{array}{l}-0.0012 \\
(0.0048)\end{array}$ \\
\hline $\begin{array}{l}\text { Mexico } \\
\text { times } \\
\text { Offshoring }\end{array}$ & $\begin{array}{c}0.0886^{* * * *} \\
(0.0227)\end{array}$ & n.a. & $\begin{array}{l}0.2108 * * \\
(0.0987)\end{array}$ & $\begin{array}{l}-0.0093 \\
(0.0132)\end{array}$ & $\begin{array}{l}0.0539 * * \\
(0.0214)\end{array}$ & $\begin{array}{c}0.1966^{* * * *} \\
(0.0617)\end{array}$ & $\begin{array}{c}0.2495 * * * \\
(0.0443)\end{array}$ & $\begin{array}{r}0.0098 \\
(0.0067)\end{array}$ \\
\hline R-squared & 0.57 & n.a. & 0.55 & 0.47 & 0.50 & 0.46 & 0.70 & 0.44 \\
\hline $\begin{array}{l}\text { Adjusted } \\
\text { R-Squared }\end{array}$ & 0.55 & n.a. & 0.53 & 0.44 & 0.47 & 0.44 & 0.68 & 0.41 \\
\hline $\begin{array}{l}\text { Number of } \\
\text { Observations }\end{array}$ & 816 & n.a. & 816 & 816 & 816 & 816 & 816 & 816 \\
\hline Notes: & $\begin{array}{l}\text { Each column reports ordi } \\
\text { employment for the perio } \\
\text { dummy, and interaction t } \\
\text { are obtained through boo } \\
5 \% \text { level; and * indicates }\end{array}$ & $\begin{array}{l}\text { least squares re } \\
90 \text { through } 200 \\
\text { between country } \\
\text { pping, using } 10 \text {, } \\
\text { ificant at the } 10\end{array}$ & $\begin{array}{l}\text { ults for a } r \\
\text { Regresso } \\
\text { and offsho } \\
00 \text { repetiti } \\
\text { level. }\end{array}$ & $\begin{array}{l}\text { ression of the } \\
\text { include a cor } \\
\text { ag dummies. } \\
\text { s. } * * * \text { indica }\end{array}$ & $\begin{array}{l}\text { innual square } \\
\text { tant term, cou } \\
\text { tandard error } \\
\text { es significant }\end{array}$ & $\begin{array}{l}\text { deviation fro } \\
\text { try dummy, } \\
\text { are in parent } \\
1 \% \text { level; } * *\end{array}$ & $\begin{array}{l}\mathrm{m} \text { the mean c } \\
\text { offshoring inc } \\
\text { hesis. Standa } \\
\text { indicates sig }\end{array}$ & $\begin{array}{l}\log \\
\text { astry } \\
\text { d errors } \\
\text { ificant at }\end{array}$ \\
\hline
\end{tabular}


Table 23. Regression results for variation in Mexico and Arizona Offshoring Industries: Annual Output

\begin{tabular}{|c|c|c|c|c|c|c|c|c|}
\hline & $\begin{array}{c}\text { Electrical Equipment, } \\
\text { Appliance, and } \\
\text { Component } \\
(335)\end{array}$ & $\begin{array}{c}\text { Transportation } \\
\text { Equipment } \\
\text { (336) }\end{array}$ & $\begin{array}{c}\text { Apparel } \\
(315)\end{array}$ & $\begin{array}{l}\text { Leather and } \\
\text { Allied } \\
\text { Product } \\
(316)\end{array}$ & $\begin{array}{l}\text { Furniture } \\
\text { and Related } \\
\text { Product } \\
(337)\end{array}$ & $\begin{array}{c}\text { Chemical } \\
(325)\end{array}$ & $\begin{array}{c}\text { Machinery } \\
\quad(333)\end{array}$ & $\begin{array}{l}\text { Food } \\
(311)\end{array}$ \\
\hline Constant & $\begin{array}{c}0.0272 \\
(0.0259)\end{array}$ & $\begin{array}{l}0.0272 * \\
(0.0164)\end{array}$ & $\begin{array}{c}0.0272 \\
(0.0642)\end{array}$ & n.a. & $\begin{array}{c}0.0272 \\
(0.0311)\end{array}$ & $\begin{array}{c}0.0272 \\
(0.0435)\end{array}$ & $\begin{array}{c}0.0272 \\
(0.0364)\end{array}$ & $\begin{array}{l}0.0272^{*} \\
(0.0133)\end{array}$ \\
\hline Mexico & $\begin{array}{l}-0.0149 \\
(0.0366)\end{array}$ & $\begin{array}{l}-0.0149 \\
(0.0232)\end{array}$ & $\begin{array}{l}-0.0149 \\
(0.0909)\end{array}$ & n.a. & $\begin{array}{l}-0.0149 \\
(0.0440)\end{array}$ & $\begin{array}{l}-0.0149 \\
(0.0616)\end{array}$ & $\begin{array}{l}-0.0149 \\
(0.0515)\end{array}$ & $\begin{array}{l}-0.0149 \\
(0.0188)\end{array}$ \\
\hline $\begin{array}{l}\text { Offshoring } \\
\text { Industry }\end{array}$ & $\begin{array}{l}0.0678^{*} \\
(0.0366)\end{array}$ & $\begin{array}{c}0.0110 \\
(0.0232)\end{array}$ & $\begin{array}{l}-0.0203 \\
(0.0909)\end{array}$ & n.a. & $\begin{array}{c}0.08138^{*} \\
(0.0440)\end{array}$ & $\begin{array}{c}0.0788 \\
(0.0616)\end{array}$ & $\begin{array}{l}-0.0151 \\
(0.0515)\end{array}$ & $\begin{array}{l}-0.0146 \\
(0.0188)\end{array}$ \\
\hline $\begin{array}{l}\text { Mexico } \\
\text { times } \\
\text { Offshoring }\end{array}$ & $\begin{array}{c}0.1342 * * * \\
(0.0518)\end{array}$ & $\begin{array}{c}0.1201 * * * \\
(0.0328)\end{array}$ & $\begin{array}{c}0.60357 * * * \\
(0.1285)\end{array}$ & n.a. & $0.2033 * * *$ & $\begin{array}{c}0.2432 * * * \\
(0.0871)\end{array}$ & $\begin{array}{c}0.3973 * * * \\
(0.0728)\end{array}$ & $\begin{array}{c}0.0783 * * * \\
(0.0266)\end{array}$ \\
\hline R-squared & 0.56 & 0.57 & 0.57 & n.a. & 0.62 & 0.50 & 0.65 & 0.36 \\
\hline $\begin{array}{l}\text { Adjusted } \\
\text { R-Squared }\end{array}$ & 0.54 & 0.55 & 0.55 & n.a. & 0.60 & 0.48 & 0.63 & 0.33 \\
\hline $\begin{array}{l}\text { Number of } \\
\text { Observations }\end{array}$ & 816 & 816 & 816 & n.a. & 816 & 816 & 816 & 816 \\
\hline Notes: & $\begin{array}{l}\text { Each column reports ord } \\
\text { for the period } 1990 \text { throu } \\
\text { interaction term between } \\
\text { through bootstrapping, } \\
\text { indicates significant at th }\end{array}$ & $\begin{array}{l}\text { y least squares } r \\
2006 \text {. Regressor } \\
\text { intry and offsho } \\
10,000 \text { repetitic } \\
\% \text { level. }\end{array}$ & $\begin{array}{l}\text { sults for a reg } \\
\text { include a con } \\
\text { ng dummies. } \\
\text { s. } * * * \text { indica }\end{array}$ & $\begin{array}{l}\text { ession of the a } \\
\text { tant term, cou } \\
\text { Standard error } \\
\text { es significant }\end{array}$ & $\begin{array}{l}\text { nual squared } \\
\text { try dummy, } \\
\text { are in parentl } \\
1 \% \text { level; } *\end{array}$ & $\begin{array}{l}\text { eviation from } \\
\text { fshoring ind } \\
\text { sis. Standar } \\
\text { ndicates sigr }\end{array}$ & $\begin{array}{l}\text { the mean of } \\
\text { stry dummy, } \\
\text { errors are o } \\
\text { ificant at } 5 \%\end{array}$ & $\begin{array}{l}\text { og output } \\
\text { and } \\
\text { tained } \\
\text { level; and * }\end{array}$ \\
\hline
\end{tabular}


Table 24. Regression results for variation in Mexico and Great Lakes Offshoring Industries: Annual Employment

\begin{tabular}{|c|c|c|c|c|c|c|c|c|}
\hline & $\begin{array}{l}\text { Electrical Equipment, } \\
\text { Appliance, and } \\
\text { Component } \\
\text { (335) }\end{array}$ & $\begin{array}{c}\text { Transportation } \\
\text { Equipment } \\
\text { (336) }\end{array}$ & $\begin{array}{c}\text { Apparel } \\
(315)\end{array}$ & $\begin{array}{l}\text { Leather and } \\
\text { Allied } \\
\text { Product } \\
(316)\end{array}$ & $\begin{array}{l}\text { Furniture } \\
\text { and Related } \\
\text { Product } \\
(337)\end{array}$ & $\begin{array}{c}\text { Chemical } \\
\text { (325) }\end{array}$ & $\begin{array}{c}\text { Machinery } \\
(333)\end{array}$ & $\begin{array}{l}\text { Food } \\
(311)\end{array}$ \\
\hline Constant & $\begin{array}{c}0.0065 \\
(0.0117)\end{array}$ & n.a. & $\begin{array}{c}0.0065 \\
(0.0473)\end{array}$ & $\begin{array}{c}0.0065 \\
(0.0161)\end{array}$ & $\begin{array}{c}0.0065 \\
(0.0107)\end{array}$ & $\begin{array}{c}0.0065 \\
(0.0307)\end{array}$ & $\begin{array}{c}0.0065 \\
(0.0221)\end{array}$ & $\begin{array}{l}0.0065^{*} \\
(0.0033)\end{array}$ \\
\hline Mexico & $\begin{array}{c}0.0048 \\
(0.0165)\end{array}$ & n.a. & $\begin{array}{c}0.0048 \\
(0.0668)\end{array}$ & $\begin{array}{c}0.0048 \\
(0.0228)\end{array}$ & $\begin{array}{c}0.0048 \\
(0.0151)\end{array}$ & $\begin{array}{c}0.0048 \\
(0.0435)\end{array}$ & $\begin{array}{c}0.0048 \\
(0.0313)\end{array}$ & $\begin{array}{c}0.0048 \\
(0.0047)\end{array}$ \\
\hline $\begin{array}{l}\text { Offshoring } \\
\text { Industry }\end{array}$ & $\begin{array}{c}0.0149 \\
(0.0165)\end{array}$ & n.a. & $\begin{array}{c}0.1014 \\
(0.0668)\end{array}$ & $\begin{array}{c}0.1368^{* * *} \\
(0.0228)\end{array}$ & $\begin{array}{l}-0.0021 \\
(0.0151)\end{array}$ & $\begin{array}{l}-0.0057 \\
(0.0435)\end{array}$ & $\begin{array}{c}0.0072 \\
(0.0313)\end{array}$ & $\begin{array}{l}-0.0056 \\
(0.0047)\end{array}$ \\
\hline $\begin{array}{l}\text { Mexico } \\
\text { times } \\
\text { Offshoring }\end{array}$ & $\begin{array}{c}0.0783 * * * \\
(0.0233)\end{array}$ & n.a. & $\begin{array}{c}0.2855^{* * *} \\
(0.0945)\end{array}$ & $\begin{array}{c}-0.1161 * * * \\
(0.0322)\end{array}$ & $\begin{array}{l}0.078 * * * \\
(0.0214)\end{array}$ & $\begin{array}{c}0.2226^{* * *} \\
(0.0615)\end{array}$ & $\begin{array}{l}0.251 * * * \\
(0.0443)\end{array}$ & $\begin{array}{l}0.0141 * * \\
(0.0067)\end{array}$ \\
\hline R-squared & 0.57 & n.a. & 0.54 & 0.56 & 0.52 & 0.46 & 0.70 & 0.44 \\
\hline $\begin{array}{l}\text { Adjusted } \\
\text { R-Squared }\end{array}$ & 0.55 & n.a. & 0.52 & 0.54 & 0.49 & 0.44 & 0.68 & 0.41 \\
\hline $\begin{array}{l}\text { Number of } \\
\text { Observations }\end{array}$ & 816 & n.a. & 816 & 816 & 816 & 816 & 816 & 816 \\
\hline Notes: & $\begin{array}{l}\text { Each column reports ordin } \\
\text { employment for the perioc } \\
\text { dummy, and interaction te } \\
\text { are obtained through boot } \\
5 \% \text { level; and * indicates }\end{array}$ & $\begin{array}{l}\text { least squares re } \\
90 \text { through } 200 \\
\text { between country } \\
\text { pping, using } 10 \text {, } \\
\text { lificant at the } 10\end{array}$ & $\begin{array}{l}\text { sults for a re } \\
\text { 6. Regressor } \\
\text { and offshor } \\
000 \text { repetitio } \\
\% \text { level. }\end{array}$ & $\begin{array}{l}\text { ression of the } \\
\text { include a con } \\
\text { ig dummies. } \\
\text { s. } * * * \text { indica }\end{array}$ & $\begin{array}{l}\text { nnual squared } \\
\text { ant term, cour } \\
\text { tandard errors } \\
\text { s significant a }\end{array}$ & $\begin{array}{l}\text { deviation fro } \\
\text { try dummy, } \\
\text { are in parentl } \\
1 \% \text { level; ** }\end{array}$ & $\begin{array}{l}\mathrm{n} \text { the mean o } \\
\text { ffshoring ind } \\
\text { esis. Standa } \\
\text { indicates sig }\end{array}$ & $\begin{array}{l}\log \\
\text { stry } \\
\text { lerrors } \\
\text { ificant at }\end{array}$ \\
\hline
\end{tabular}


Table 25. Regression results for variation in Mexico and Great Lakes Offshoring Industries: Annual Output

\begin{tabular}{|c|c|c|c|c|c|c|c|c|}
\hline & $\begin{array}{l}\text { Electrical Equipment, } \\
\text { Appliance, and } \\
\text { Component } \\
(335)\end{array}$ & $\begin{array}{c}\text { Transportation } \\
\text { Equipment } \\
\text { (336) }\end{array}$ & $\begin{array}{c}\text { Apparel } \\
(315)\end{array}$ & $\begin{array}{l}\text { Leather and } \\
\text { Allied } \\
\text { Product } \\
(316)\end{array}$ & $\begin{array}{l}\text { Furniture } \\
\text { and Related } \\
\text { Product } \\
(337)\end{array}$ & $\begin{array}{c}\text { Chemical } \\
(325)\end{array}$ & $\begin{array}{c}\text { Machinery } \\
\text { (333) }\end{array}$ & $\begin{array}{l}\text { Food } \\
(311)\end{array}$ \\
\hline Constant & $\begin{array}{c}0.0035 \\
(0.0180)\end{array}$ & $\begin{array}{c}0.0035 \\
(0.0142)\end{array}$ & $\begin{array}{c}0.0035 \\
(0.0640)\end{array}$ & n.a. & $\begin{array}{c}0.0035 \\
(0.0269)\end{array}$ & $\begin{array}{c}0.0035 \\
(0.0411)\end{array}$ & $\begin{array}{c}0.0035 \\
(0.0362)\end{array}$ & $\begin{array}{c}0.0035 \\
(0.0132)\end{array}$ \\
\hline Mexico & $\begin{array}{c}0.0088 \\
(0.0254)\end{array}$ & $\begin{array}{c}0.0088 \\
(0.0201)\end{array}$ & $\begin{array}{c}0.0088 \\
(0.0905)\end{array}$ & n.a. & $\begin{array}{c}0.0088 \\
(0.0380)\end{array}$ & $\begin{array}{c}0.0088 \\
(0.0581)\end{array}$ & $\begin{array}{c}0.0088 \\
(0.0512)\end{array}$ & $\begin{array}{c}0.0088 \\
(0.0187)\end{array}$ \\
\hline $\begin{array}{l}\text { Offshoring } \\
\text { Industry }\end{array}$ & $\begin{array}{c}0.0050 \\
(0.0254)\end{array}$ & $\begin{array}{c}0.0145 \\
(0.0201)\end{array}$ & $\begin{array}{c}0.0137 \\
(0.0905)\end{array}$ & n.a. & $\begin{array}{c}0.0117 \\
(0.0380)\end{array}$ & $\begin{array}{c}0.0092 \\
(0.0581)\end{array}$ & $\begin{array}{c}0.0071 \\
(0.0512)\end{array}$ & $\begin{array}{c}0.0014 \\
(0.0187)\end{array}$ \\
\hline $\begin{array}{l}\text { Mexico } \\
\text { times } \\
\text { Offshoring }\end{array}$ & $\begin{array}{l}0.197 * * * \\
(0.0359)\end{array}$ & $\begin{array}{c}0.1167 * * * \\
(0.0284)\end{array}$ & $\begin{array}{c}0.5695 * * * \\
(0.1280)\end{array}$ & n.a. & $\begin{array}{l}0.273 * * * \\
(0.0538)\end{array}$ & $\begin{array}{c}0.3128 * * * \\
(0.0822)\end{array}$ & $\begin{array}{l}0.375^{* * *} \\
(0.0724)\end{array}$ & $\begin{array}{c}0.0623 * * * \\
(0.0264)\end{array}$ \\
\hline R-squared & 0.69 & 0.62 & 0.57 & n.a. & 0.66 & 0.51 & 0.65 & 0.35 \\
\hline $\begin{array}{l}\text { Adjusted } \\
\text { R-Squared }\end{array}$ & 0.67 & 0.60 & 0.55 & n.a. & 0.64 & 0.48 & 0.63 & 0.32 \\
\hline $\begin{array}{l}\text { Number of } \\
\text { Observations }\end{array}$ & 816 & 816 & 816 & n.a. & 816 & 816 & 816 & 816 \\
\hline Notes: & $\begin{array}{l}\text { Each column reports ordi } \\
\text { for the period } 1990 \text { throu } \\
\text { interaction term between } \\
\text { through bootstrapping, us } \\
\text { * indicates significant at }\end{array}$ & $\begin{array}{l}\text { y least squares } \mathrm{r} \\
2006 \text {. Regressor } \\
\text { intry and offshor } \\
10,000 \text { repetitio } \\
10 \% \text { level. }\end{array}$ & $\begin{array}{l}\text { sults for a re } \\
\text { s include a cc } \\
\text { ing dummies } \\
\text { ns. } * * * \text { indic }\end{array}$ & $\begin{array}{l}\text { ression of the } \\
\text { astant term, co } \\
\text { Standard erro } \\
\text { ates significant }\end{array}$ & $\begin{array}{l}\text { innual squared } \\
\text { intry dummy, } \\
\text { s are in parentl } \\
\text { at } 1 \% \text { level; ** }\end{array}$ & $\begin{array}{l}\text { deviation fro } \\
\text { ffshoring inc } \\
\text { esis. Standa } \\
\text { indicates sig }\end{array}$ & $\begin{array}{l}\mathrm{n} \text { the mean o } \\
\text { ustry dummy } \\
\text { dd errors are } \\
\text { nificant at } 5^{\circ}\end{array}$ & $\begin{array}{l}\text { log output } \\
\text { and } \\
\text { btained } \\
0 \text { level; and }\end{array}$ \\
\hline
\end{tabular}


Table 26. Regression results for intensive and extensive margins

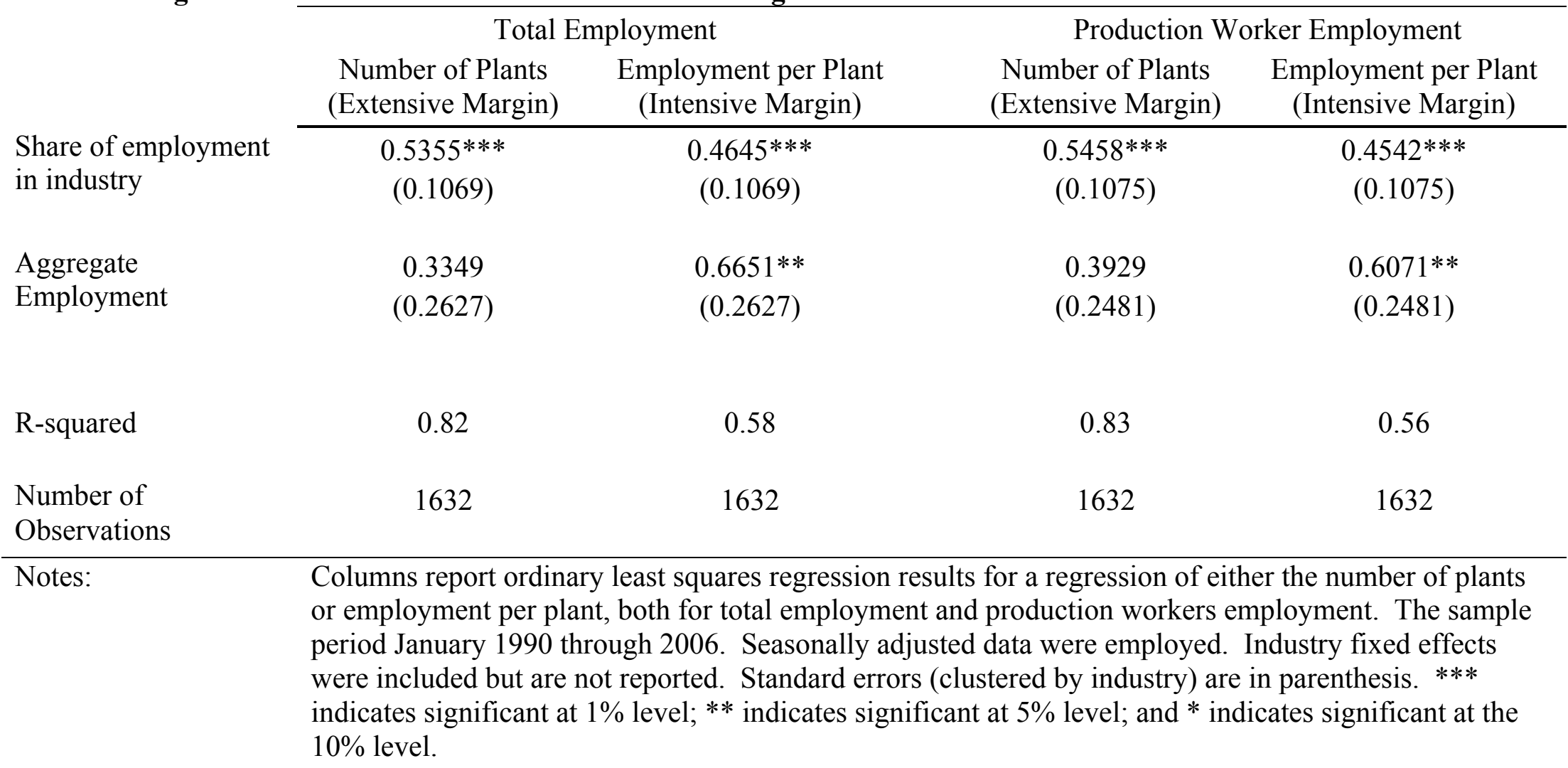


Figure 1. Log-difference in Output

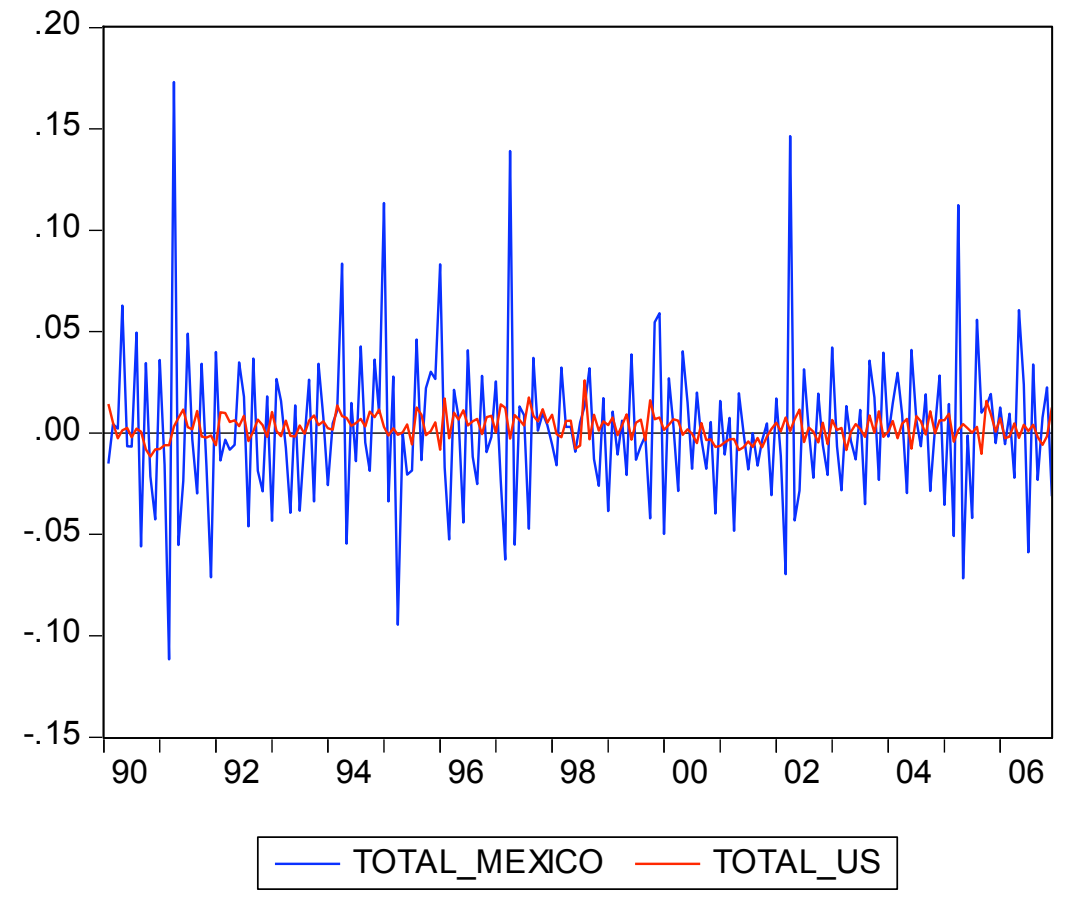

Notes: Manufacturing output data for Mexico is real in pesos. Manufacturing output data for the U.S. is the total manufacturing production index. Data are seasonally adjusted and log-transformed. 
Figure 2. Log-difference in Total Employment

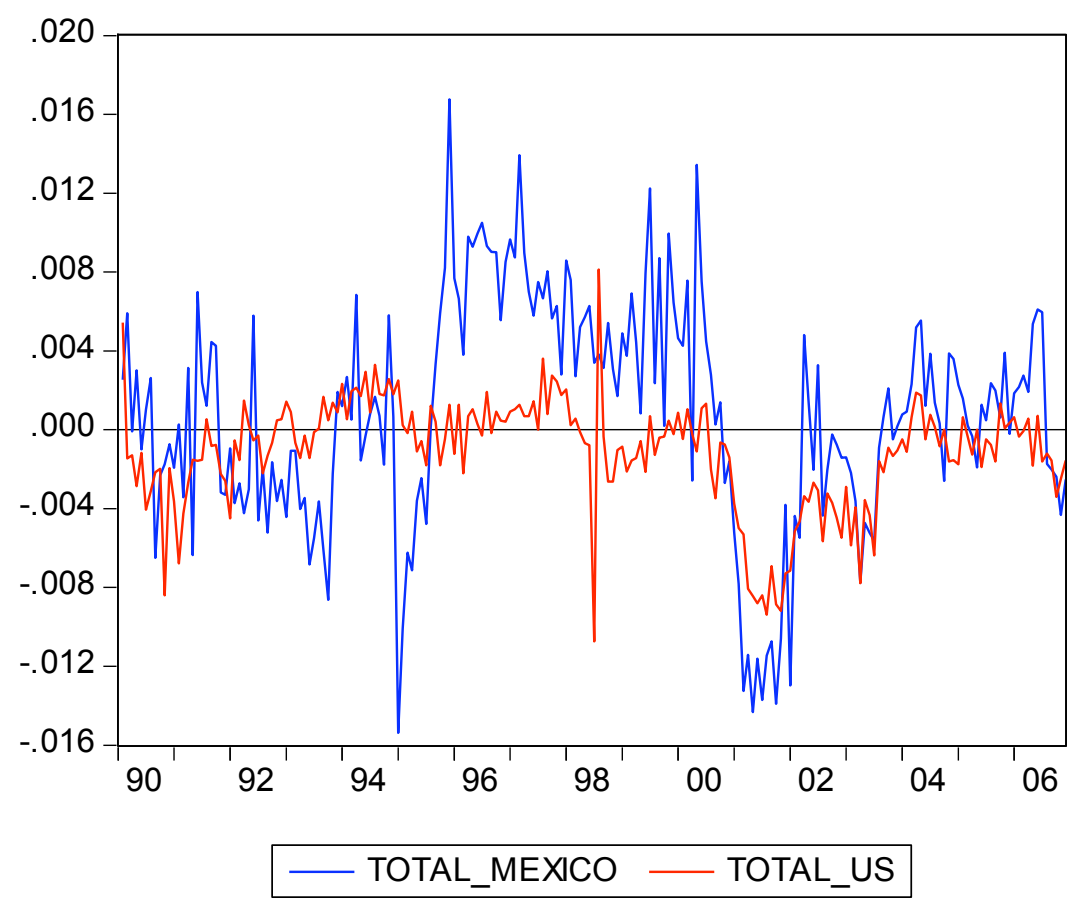

Notes: Total employment data for both Mexico and the U.S. correspond to total manufacturing employment. Data are seasonally adjusted and log-transformed. 
Figure 3. Log-difference in Production Worker Employment

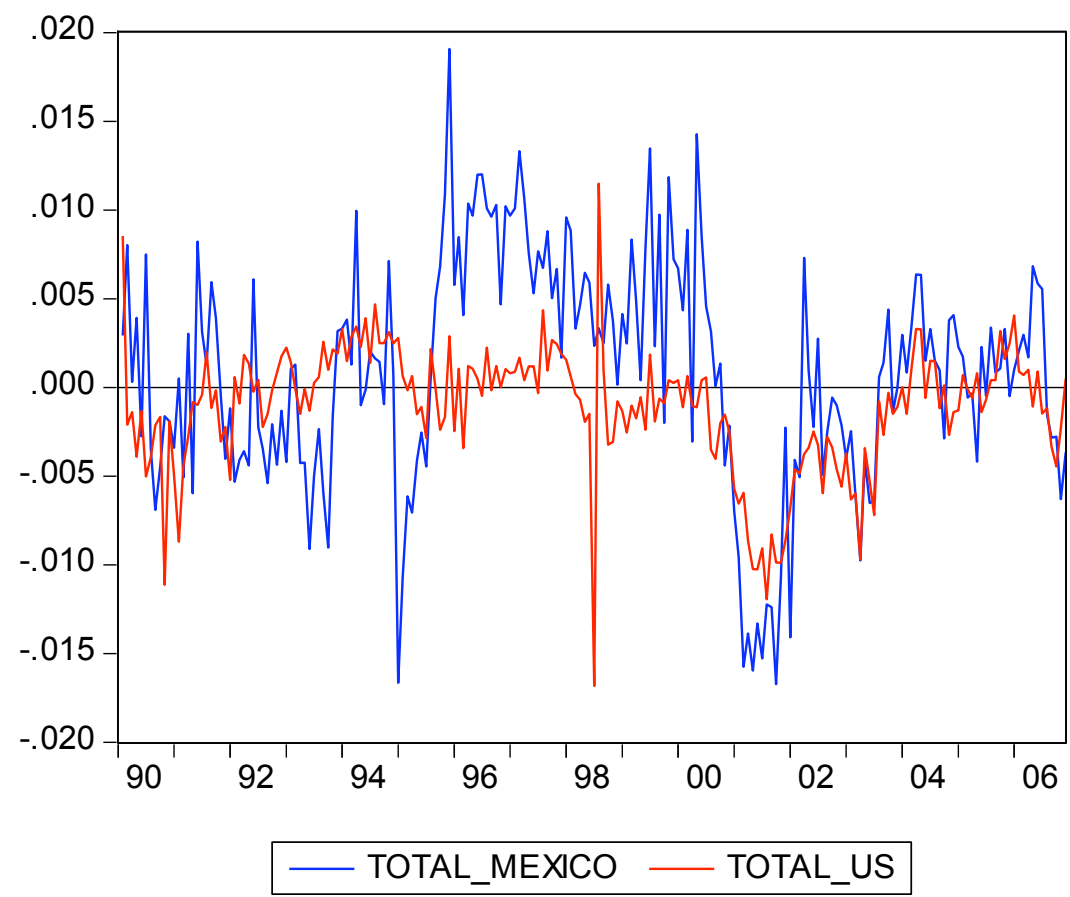

Notes: Production worker employment data for both Mexico and the U.S. correspond to manufacturing production worker employment. Data are seasonally adjusted and log-transformed. 


\section{Figure 4. Log-difference in Output by Sector}
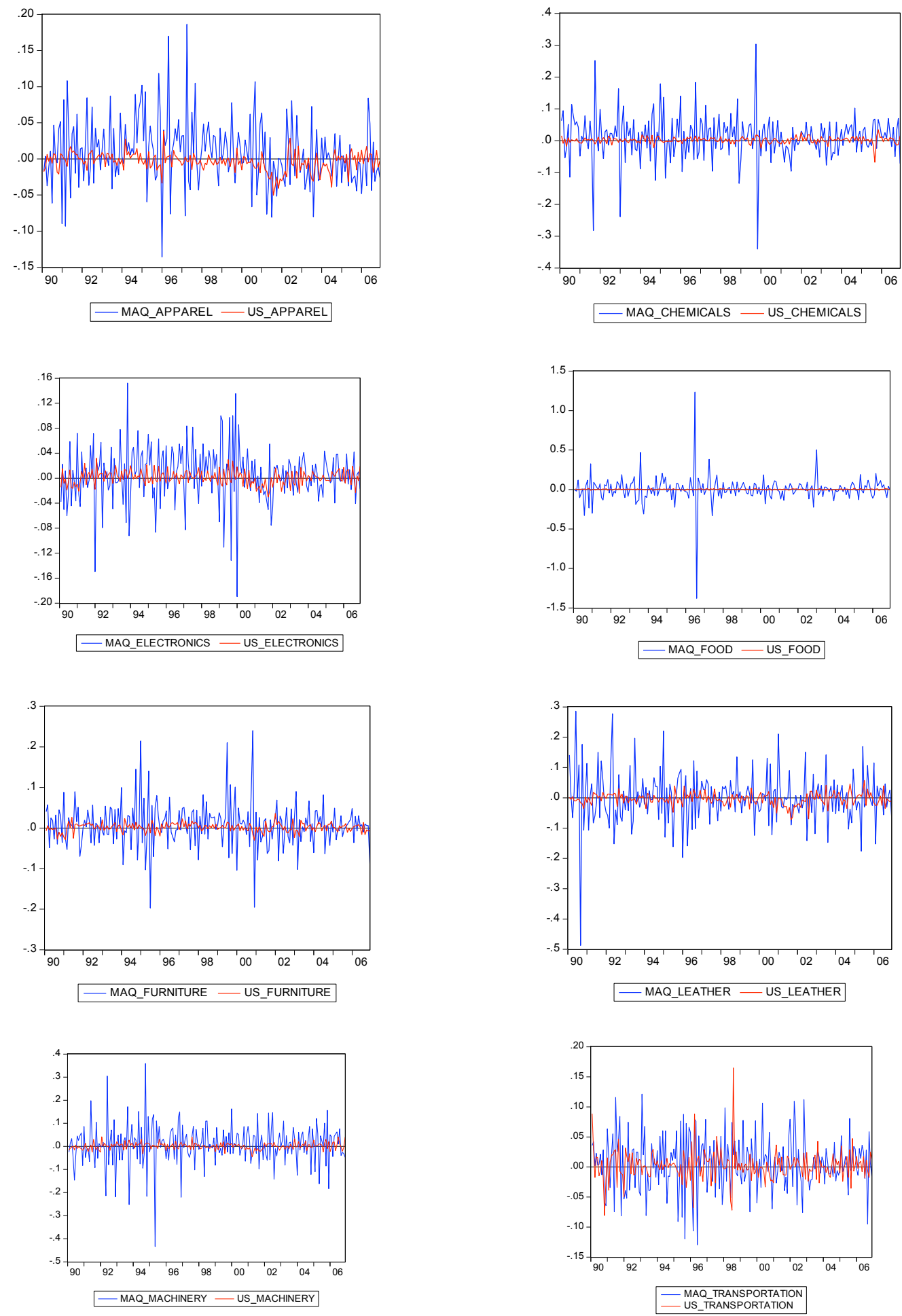

Notes: Output data for Mexico's offshoring sectors is real in pesos. Output data for the U.S.' offshoring sectors is production index. Data are seasonally adjusted and log-transformed. 


\section{Figure 5. Log-difference in Total Employment by Sector}
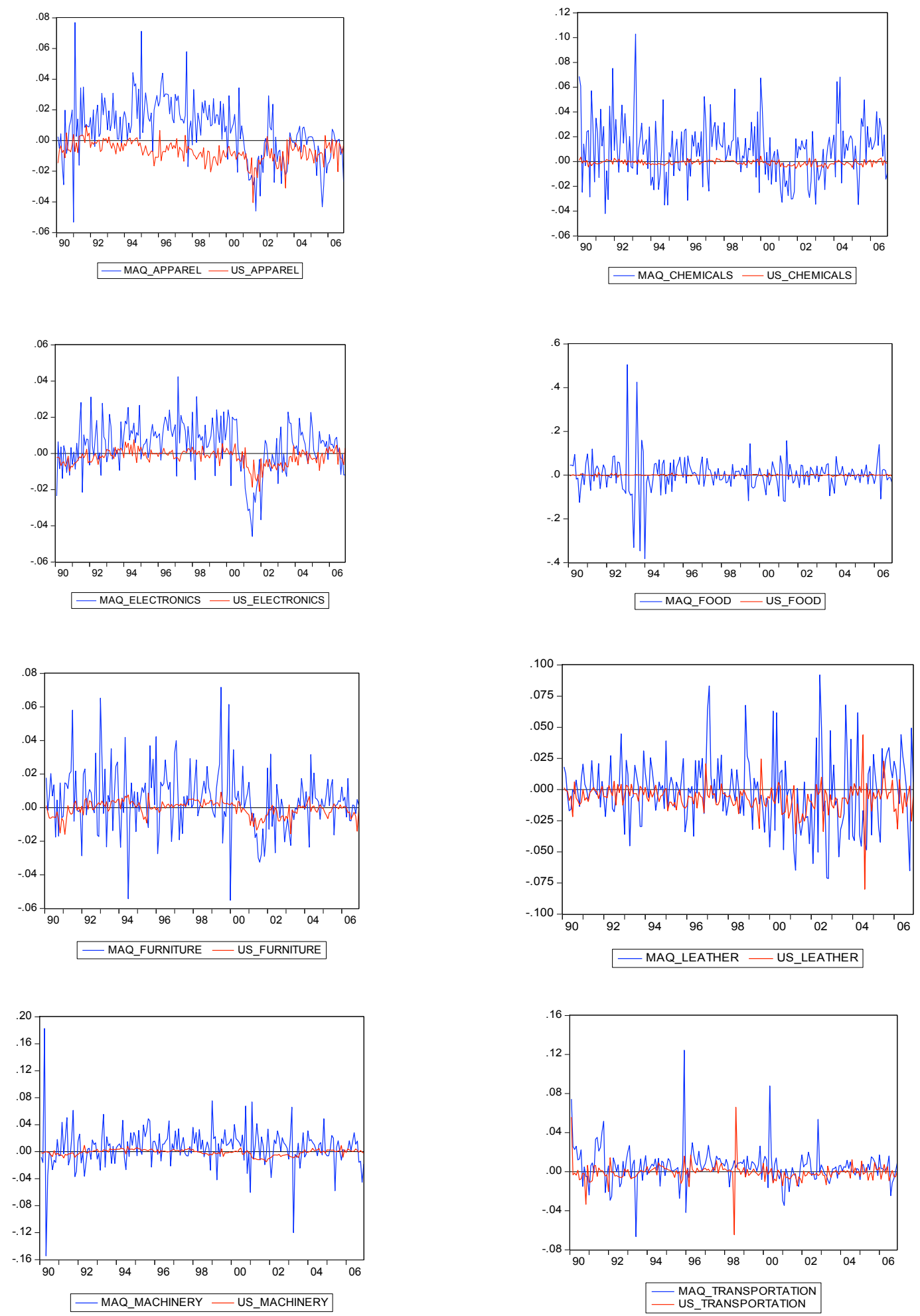

Notes: Total employment data for offshoring sectors in both Mexico and the U.S. correspond to total manufacturing employment. Data are seasonally adjusted and log-transformed. 
Figure 6. Log-difference in Production Worker Employment by Sector
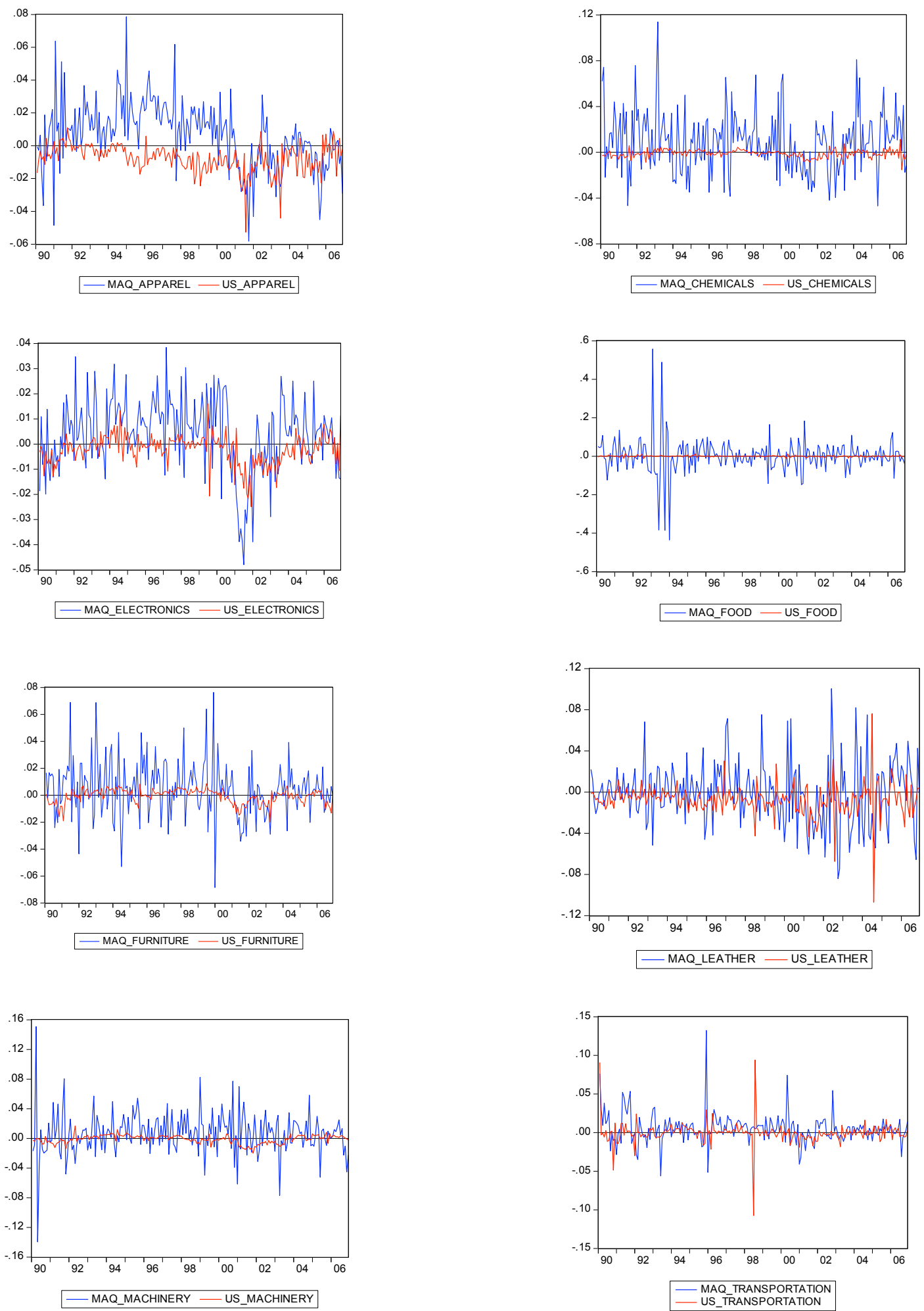

Notes: Production worker employment data for offshoring sectors in both Mexico and the U.S. correspond to manufacturing production worker employment. Data are seasonally adjusted and log-transformed. 